\title{
Judas or Jesus' Other Disciples? The Old Testament or Jesus' Word? A Mysterious Reference to the "Scripture" in John 17:12
}

\author{
ADAM KUBIŚ \\ Institute of Biblical Studies, The John Paul II Catholic University of Lublin, Poland \\ e-mail: adamkubis@kul.pl \\ ORCID: 0000-0003-4961-2254
}

\begin{abstract}
The fulfillment of "the Scriptures" in John 17:12 has long been a bone of contention among commentators on the Fourth Gospel. The majority of authors have argued that

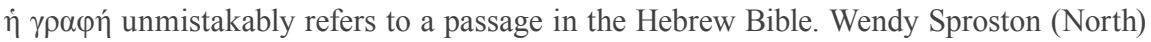
and Francis Moloney, however, picking up on an earlier observation by Edwin Freed, suggest Jesus' own words as a more appropriate referent of $\dot{\eta} \gamma \rho \alpha \varphi \eta$ in this verse. The issue of the correct scriptural referent is intrinsically connected with the question of the thematic referent within the verse in question. As it turns out, the fulfillment of the scripture can refer to either the tragic fate of Judas or the preserving of Jesus' other disciples. The article surveys recent scholarship on these issues in order to identify the most convincing solutions.
\end{abstract}

KeYwords: The Gospel of John, John 17:12, Judas Iscariot, Scripture, the use of the OT in the NT

$\mathrm{T}$ here is an intriguing disagreement within current scholarship regarding the semantics of $\dot{\eta} \gamma \rho \alpha \varphi \eta$ in John 17:12. The study of Francis J. Moloney from $2005^{1}$, as well as the earlier article by Wendy E. Sproston from $1987^{2}$, put forward

$1 \quad$ F.J. Moloney, "The Gospel of John as Scripture", $C B Q 67$ (2005) 454-468, especially 461; reprinted in F.J. Moloney, The Gospel of John. Text and Context (BIS 72; Boston - Leiden: Brill 2005) 333347. The suggestion about understanding $\dot{\eta} \gamma \rho \alpha \varphi \eta$ in John 20:9 as a "Scripture" was already made in F.J. Moloney, Glory not Dishonor: Reading John 13-21 (Minneapolis, MN: Fortress 1998) $162-$ 163; F.J. Moloney, The Gospel of John (SP 4; Collegeville, MN: The Liturgical Press 1998) 520-521, 523. On the thesis that the author of the Fourth Gospel regarded his story of Jesus as "Scripture" see also F.J. Moloney, "What Came First - Scripture or Canon? The Gospel of John as a Test Case", Salesianum 68 (2006) 7-20, reprinted in F.J. Moloney, Johannine Studies 1975-2017 (WUNT 372; Tübingen: Mohr Siebeck 2017) 65-76; F.J. Moloney, “«For as yet they did not know the Scripture» (John 20,9). A Study in Narrative Time", ITQ 79/2 (2014) 97-111; reprinted in F.J. Moloney, Johannine Studies 1975-2017 (WUNT 372; Tübingen: Mohr Siebeck 2017) 505-519. Moloney's work is based on the intuitions found in D. Moody Smith, "When Did the Gospels Become Scripture?", JBL 119 (2000) 3-20; A. Obermann, Die christologische Erfüllung der Schrift im Johannesevangelium: Eine Untersuchung zur johanneischen Hermeneutik anhand der Schriftzitate (WUNT 2/83; Tübingen: Mohr Siebeck 1996) 409-22, especially 418-22.

2 W.E. Sproston, "«The Scripture» in John 17:12", Scripture: Meaning and Method. Essays Presented to Anthony Tyrrell Hanson for His Seventieth Birthday (ed. B.P. Thompson) (Hull: Univer- 
the view that the noun $\dot{\eta} \gamma \rho \alpha \varphi \eta$ refers to the word that Jesus had spoken, attested first in 6:39, partly in 10:28 and again in 18:9. The two authors have independently (and unintentionally, in the case of Moloney) picked up on a suggestion by Edwin D. Freed (1965), which also arose in the commentary by Craig S. Keener (2003). Edwin Freed and Craig Keener judged the semantics of $\dot{\eta} \gamma \rho \alpha \varphi \eta$ as ambiguous in its present context of 17:12. ${ }^{3}$ However, for Wendy Sproston and Francis Moloney the term is no longer ambiguous, but clearly has one sole meaning referring to Jesus' utterance. This novel approach deserves a serious treatment, since the majority of recognized authors dealing with the Fourth Gospel opt for a different view. Specifically, in prevailing scholarly opinion $\dot{\eta} \gamma \rho \alpha \varphi \eta$ unmistakably alludes to a precise Old Testament passage. The novel approach arises from the fact that, although in Jn 17:12 a quotation formula "plainly directs the reader's attention to the Old Testament, no discrete Old Testament passage is actually cited." ${ }^{4}$ In this way, there is room for speculation both in ascribing a totally new meaning to $\dot{\eta}$

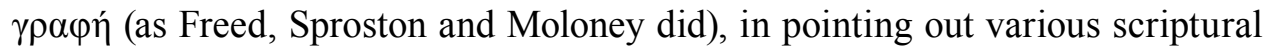
referents (as the majority of commentators do), or in arguing that the general sense of the whole Scripture as such or at least a few scriptural passages is/ are intended by $\dot{\eta} \gamma \rho \alpha \varphi \eta$ in Jn 17:125. That being so, the present article aims at examining the verse in question, in order to assess the arguments of the above interpretations and propose the most convincing stance. ${ }^{6}$

sity of Hull 1987) 24-36; reprinted as W.E.S. North, “«The Scripture» in John 17.12”, A Journey Round John. Tradition, Interpretation and Context in the Fourth Gospel (LNTS 534; London et al.: Bloomsbury 2015) 45-56.

3 E.D. Freed, Old Testament Quotations in the Gospel of John (NT.S 11; Leiden: Brill 1965) 57: "In 17:12 the "scripture" may refer to Ps $41: 10$ quoted in 13:18. But since the passage is obviously referred to in 18:9 where the words of Jesus are spoken of as having fulfillment apart from any appeal to the O.T., it seems that in 17:12 $\dot{\eta} \gamma \rho \alpha \varphi \eta$ also refers to the words of Jesus formerly spoken in 6:39,70f. and now having fulfillment (cf. also 13:2,27)". C.S. Keener, The Gospel of John. A Commentary (Peabody, MA: Hendrickson 2003) 1059: "When John later refers back to this text [17:12], however, it is not only that Scripture (the Hebrew Bible or its Greek translations) might be fulfilled but also that the 'word' of Jesus might be fulfilled (18:9); for John, both are God's message."

4 B. Schuchard, Scripture within Scripture. The Interrelationship of Form and Function in the Explicit Old Testament Citations in the Gospel of John (SBLDS 133; Atlanta, GA: Scholars Press 1992) xiii-xiv. Cf. W. Klassen, Judas. Betrayer or Friend of Jesus? (Minneapolis, MN: Fortress 1996) 152: "It is not clear what scripture is here alluded to."

5 See J.R. Michaels, The Gospel of John (NICNT; Grand Rapids, MI: Eerdmans 2010) 870: "it is closer to 19:28, 'that the Scripture might be completed,' where [...] no one biblical text is in view. Quite possibly, readers of John's Gospel were expected to be familiar in a general way with the notion that Judas's betrayal and his subsequent fate were prophesied in Scripture (see not only 13:18 and Acts 1:20, but also Matt 27:9)."

6 There is also one more way of dealing with a difficulty. Jürgen Becker argued that the whole phrase,

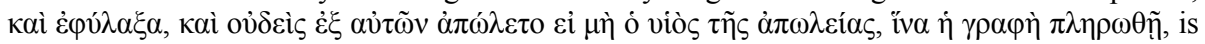
a latter addition by an editor who had a special interest in the figure of Judas. J. Becker, „Aufbau, Schichtung und theologiegeschichtliche Stellung des Gebetes in Johannes 17", ZNW 60 (1969) 56-83. As evidence of editing, J. Becker points to five features of John 17:12, which were handsomely summarized by Urban C. von Wahlde: “(1) the seemingly awkward repetition of $\tau \eta \rho \varepsilon ́ t v$ and 
The question of the precise semantics of $\dot{\eta} \gamma \rho \alpha \varphi \eta$ is intrinsically connected with the issue of a right referent of this noun within John 17:12. As it turns out, it can refer either to "the son of perdition", identified with Judas, or to the other disciples. A careful reader of verse 17:12 can easily single out the following motifs: (1) the guarding ( $\tau \eta \rho \varepsilon ́ \omega)$ and watching over $(\varphi \nu \lambda \alpha ́ \sigma \sigma \omega)$ of the disciples by Jesus; (2) the Father as a giver ( $\delta$ í $\delta \omega \mu$ ); (3) the name of God, the Father ( $\tau$ ó óvo $\mu \alpha$ бov); (4) "the unassailability of the flock of God because of his guardian power" , i.e., none will perish ( $\dot{\alpha} \pi \hat{\prime} \lambda \lambda \nu \mu \mathrm{u})$; (5) the figure of Judas, called "the son of perdition" (ó viò $\varsigma \tilde{\eta} \varsigma \dot{\alpha} \pi \omega \lambda \varepsilon i ́ \alpha \varsigma)$; and finally, (6) the fulfilment of the Scripture (iv $\alpha \dot{\eta}$ $\gamma \rho \alpha \varphi \grave{\eta} \pi \lambda \eta \rho \omega \theta \tilde{\eta})$. All these themes or motifs are by no means exclusive to 17:12, but are widely spread throughout the Fourth Gospel. Focusing on the last, sixth

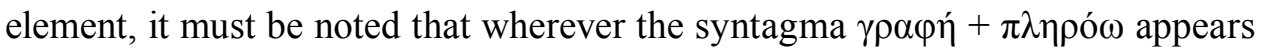
in John's Gospel, the OT quotation is nearby, within the text. ${ }^{8}$ This suggests that the referent of $\dot{\eta} \gamma \rho \alpha \varphi \eta$ is already contained in 17:12, as the presence of any OT reference in the immediately following verse (17:13) is implausible. That being so, the phrase iv $\alpha \dot{\eta} \gamma \rho \alpha \varphi \grave{\eta} \pi \lambda \eta \rho \omega \theta \tilde{\eta}$ can refer either: (a) to the figure of Judas, mentioned in the text as ó viò $\tau \tilde{\eta} \varsigma \dot{\alpha} \pi \omega \lambda \varepsilon i \alpha_{\varsigma}$ (motif no. 5), or (b) to the rest of the

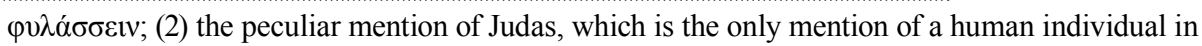
the entire prayer of chap 17; (3) the mention of 'fulfillment' which, according to Becker, reflects a promise/fulfillment schema not present elsewhere in the prayer; (4) the appearance of 'son of perdition,' a title which appears nowhere else in the Johannine literature; and finally (5) the fact that v13 follows v12a better than it does v12e." After U.C. von Wahlde, "Judas, the Son of Perdition, and the Fulfillment of Scripture in John 17:12", The New Testament and Early Christian Literature in Greco-Roman Context. Studies in Honor of David E. Aune (ed. J. Fotopoulos) (NT.S 122; Leiden: Brill 2006) 173-174. Already G.Ch. Knapp, in his critical edition of the Greek New Testament, marked a whole second part of 17:12 as a kind of parenthesis (an author's additional remark): oú

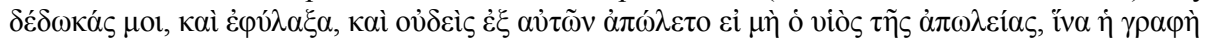
$\pi \lambda \eta \rho \omega \theta \tilde{\eta}$. G.Ch. Knapp, H KAINH $\Delta \mathrm{IA \Theta HKH.} \mathrm{Novum} \mathrm{Testamentum} \mathrm{Graece.} \mathrm{Revognavit} \mathrm{atque}$ insignioris lectionum varietatis et argumentorum notations subiunxit (Halle: Orphanotropheum 1787, $\left.{ }^{5} 1840\right)$ ad loc. R. Schnackenburg, The Gospel According to St John, Volume Three. Commentary on Chapters 12-21 (Herder's Theological Commentary on the New Testament; New York, NY: Crossroad 1990) 182, argues: “This consideration of the 'son of perdition' certainly seems to be superfluous in this context (v. 13 follows v. 12a quite easily). It is not in accordance with the style of the intercession and its details (the new beginning, striking words and the reference to Scripture) make it quite different from the rest. For this reasons, it may well have been introduced by a second author, possibly an editor (...). On the other hand, the reason for excluding the digression about the 'son of perdition' from the original prayer are also not completely convincing." The idea of deeming a part of Jn 17:12 a later gloss does not really solve the problem because even the final editor must have had a precise semantics of $\dot{\eta} \gamma \rho \alpha \varphi \eta$ in mind. This point of critique was made by U.C. von Wahlde, "Judas", 174: "the presence of editing would only push the question of the source being referred to back to the editor rather than placing it in the lap of the evangelist."

7 J.N. Birdsall, "John X.29", JTS 11 (1960) 344. Cf. also C.K. Barrett, The Gospel according to St John. An Introduction with Commentary and Notes on the Greek Text (London: SPCK 1978) 382.

8 Jn 13:18; 19:24.36. See also the case of the synonymic terms ó $\lambda$ ó $\gamma \circ \varsigma$ and $\pi \lambda \eta \rho$ ó $\omega$ in 12:38 and 15:25 followed by direct OT quotations. At this point we note also that in 18:9 the lexemes ó $\lambda$ ó $\gamma o \zeta$ and $\pi \lambda \eta \rho$ ó $\omega$ introduce the quotation of Jesus' words, whereas in 18:32 the same terms refer to a direct allusion to Jesus' prediction of his death. 
disciples, about whom it is said that, positively, they were guarded and watched (no. 1) and, negatively, that they did not perish (no. 4). The theme of the Father (no. 2), a giver of his name (no. 3), is in this case inextricably connected with the motif of disciples.

In what follows, both possibilities will be considered: the scriptural referent of $\dot{\eta} \gamma \rho \alpha \varphi \eta$ identified first with the figure of Judas and then with the rest of Jesus' disciples. In fact, the differentiation of personal subjects to which $\dot{\eta} \gamma \rho \alpha \varphi \eta$ can be referred reflects to some extent the main problematic issue, namely the semantics of $\dot{\eta} \gamma \rho \alpha \varphi \eta$. If $\dot{\eta} \gamma \rho \alpha \varphi \eta$ points towards Judas, the term refers to a scriptural passage, understood as a reference to either the OT or the NT. If however

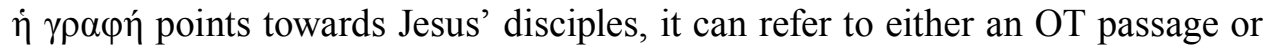
to Jesus' words written in the Fourth Gospel. Thus the following analysis will discuss, first, all possible scriptural referents concerned with Judas (understood as a reference to the OT or the NT), followed by any referents dealing with Jesus' disciples, namely OT passages and Jesus' words found in the Gospel of John understood as the Scripture.

\section{Reference to Judas}

The Johannine phrase ó viò $\tau \tilde{\eta} \varsigma \dot{\alpha} \pi \omega \lambda \varepsilon i ́ \alpha \varsigma$ does not have any strict parallel in the Old Testament, in either its Hebrew nor Greek versions. ${ }^{9}$. As a result, there is a plethora of various scholarly proposals as to a potential scriptural referent to the Johannine ó viòs $\tau \tilde{\eta} \varsigma \dot{\alpha} \pi \omega \lambda \varepsilon i ́ \alpha \varsigma$. In attempting to find a Hebrew counterpart for this Greek expression, it is necessary to analyze the occurrences of the noun $\dot{\alpha} \pi \omega \dot{ } \lambda \varepsilon 1 \alpha$. As it turns out, there is no terminologically consistent equivalence between the Hebrew Bible and the LXX with regard to this noun. The Hebrew Vorlage attests a wide diversity of lexemes which are rendered by the term $\dot{\alpha} \pi \omega \dot{\lambda} \varepsilon 1 \alpha$ in the LXX. A few examples, like Isa 34:5 and Ben Sira 16:9 and 46:6, would

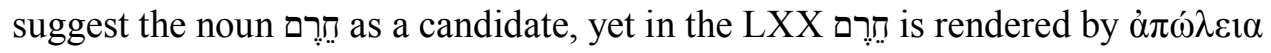
only twice (Is 34:5; Ben Sira 16:9). ${ }^{10}$ There is, however, a somewhat greater prev-

9 R. Reim, Studien zum alttestamentlichen Hintergrund des Johannesevangeliums (SNTSMS 22; Cambridge: Cambridge University Press 1974) 45, states: "Sucht man im AT nach einer Schrifts-

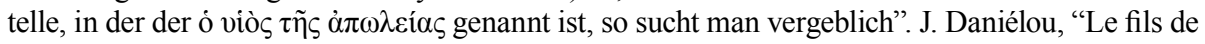
perdition (Joh., 17, 12)", Mélanges d'histoire des religions offerts à Henri-Charles Puech (Paris: Presses universitaires de France 1974) 188: "cette expression... ne se trouve pas dans l'Ancien Testament."

10 Whenever context allowed, the LXX employed the terms $\alpha v \alpha \dot{\alpha} \theta \varepsilon \mu \alpha / \dot{\alpha} v \alpha \dot{\alpha} \theta \eta \mu \alpha$ and the verb $\dot{\alpha} v \alpha \theta \varepsilon \mu \alpha \tau i \zeta \omega$ in order to render the noun תֶֶ and the verb (hiphil and hophal). Specifically, the

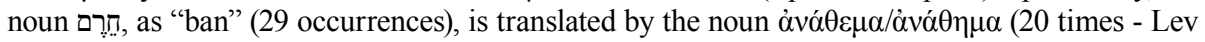
27:28bis; Dtr 7:26bis; 13:16.18; Jos 6:17.18thrice; 7:1bis.11.12bis.13bis; 22:20; 1 Ch 2:7; Zach 14:11) and in two cases by its verbal forms $\dot{\alpha} v \alpha \tau i \theta \eta \mu \mathrm{(Lev} \mathrm{27:29)} \mathrm{and} \alpha \dot{v} \alpha \theta \varepsilon \mu \alpha \tau i \zeta \zeta \omega(\mathrm{Nu} 18: 14)$. The rest of the occurrences are rendered by other terms: $\grave{\varepsilon} \xi o \lambda \varepsilon \dot{\varepsilon} \theta \rho \varepsilon v \mu \alpha$ - "destruction" (1 Sm 15:21); $\alpha$ ó $\rho 1 \sigma \mu \alpha$ 
alence of terms related to the root (qal "to perish, become lost" - Dtr 4:26; 8:19; Prov 28:28; Job 11:20; Oba 1:12; piel: "destroy, exterminate" - Dtr 12:2; Jr 12:17); אִָרָדָ ("lost thing” - Ex 22:8; Lev 5:22.23; Dtr 22:3; 30:18); tion" - Est 8:9); אִבֵּדוֹן ("realm of the dead" - Ps 88:12; Prov 15:11; 27:20; Job 26:6; 28:22). ${ }^{11}$ This diversity simply proves that a terminological study of $\alpha \dot{\pi} \omega \dot{\lambda} \varepsilon 1 \alpha$ in the LXX in search of its Hebrew Vorlage will not be of great help in elucidating the meaning of the Johannine ó viòs $\tau \tilde{\eta} \varsigma \dot{\alpha} \pi \omega \lambda$ sías.

However, Biblical Hebrew does offer a formation analogous to the Johannine ó viòs $\tau \tilde{\eta} \varsigma \alpha \dot{\alpha} \pi \omega \lambda \varepsilon i \alpha \varsigma$, namely the idiomatic construction or adjective). It is a common way of describing an individual in the Semitic languages. Let us consider a few examples. First, in 1 Sam 14:52 the expression

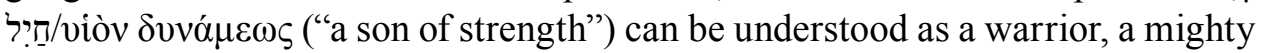

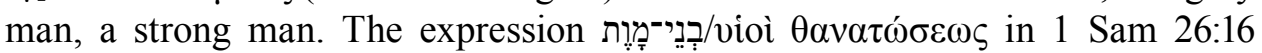
means literally "sons of death" (MT) or "sons of execution" (LXX), but in the context it means that they deserve to die. The same meaning can be applied to

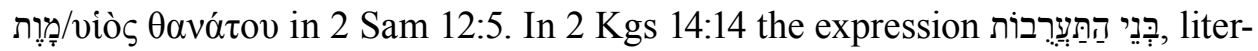
ally translated as "the sons of the pledges", means hostages, while its Septuagint

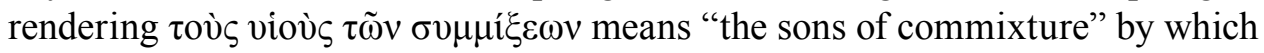
one should also understand hostages. According to Robert H. Lightfoot, this Semitic construction, which is well-attested in the New Testament Greek, conveys

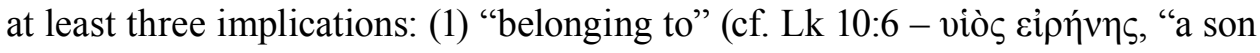

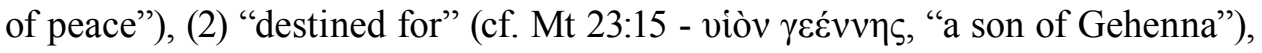

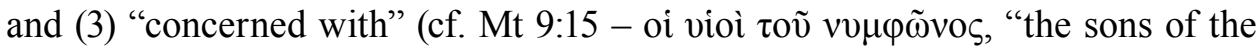
wedding hall/bridal chamber"). ${ }^{12}$ In the Fourth Gospel, besides the very common

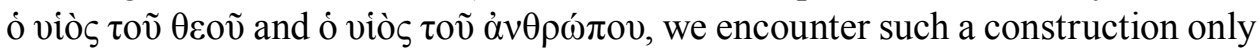
once, namely vioì $\varphi \omega \tau$ tós in 12:36. ${ }^{13}$ Taking into account the idiomatic character

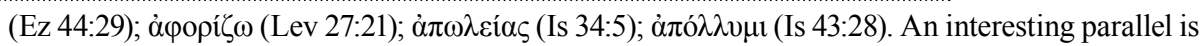

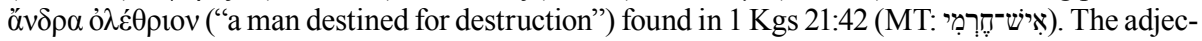
tive ỏ $\lambda \dot{\varepsilon} \theta \rho ı \varsigma$ means deadly, destructive. In the last occurrence of חֶ in Jos 7:15 there is no direct Greek rendering, although the conceptual link between חרִֶ and someone's death is present. The direct connection between חֶר and the lot of an individual is seen in Lev 27:29 - No one who may

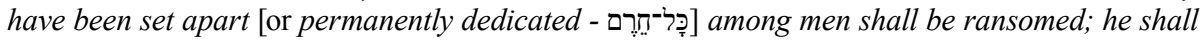
surely be put to death.

11 A few other examples of Hebrew lexemes which are rendered by $\alpha \dot{\alpha} \omega \dot{\lambda} \boldsymbol{1} \varepsilon 1 \alpha$ in LXX: root expire, die" - Nm 20:3); הום ("to throw into confusion" - Dtr 7:23); איד ("final] disaster" - Dtr

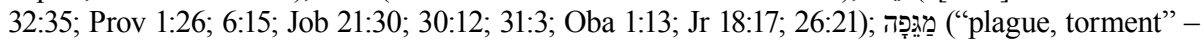
1Ch 21:17); שמד (hiphil: "to exterminate" - Est 7:4; Ez 25:7); שחת (hiphil "to ruin" - Prov 6:32; Is

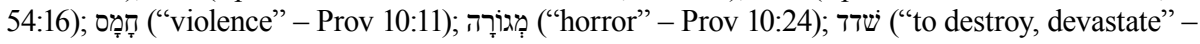

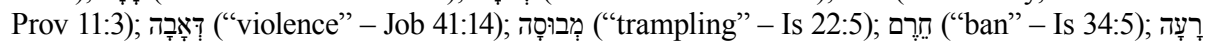

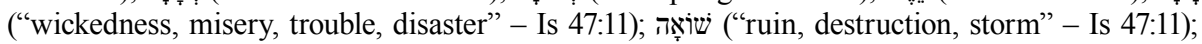

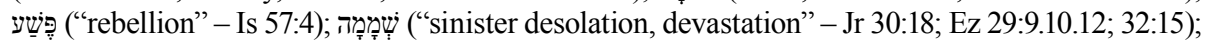

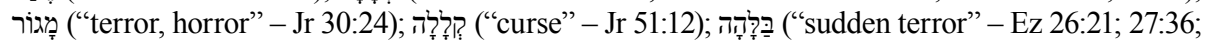

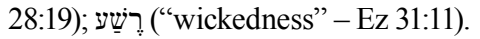

12 R.H. Lightfoot, St. John's Gospel. A Commentary (Oxford: Oxford University Press 1956) 301.

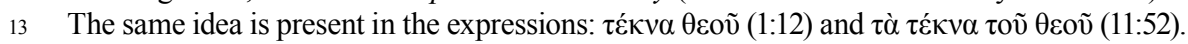


of this construction, Raymond E. Brown explained the semantics of ó viòs $\tau \tilde{\eta} \varsigma$ $\dot{\alpha} \pi \omega \lambda \varepsilon i \alpha_{\alpha}$ in the following way: "the son of perdition' refers to one who belongs to the realm of damnation and is destined to final destruction." ${ }^{14}$ Leon Morris focused on the former meaning, excluding the latter. He argued that the phrase o viò $\tau \tilde{\eta} \varsigma \dot{\alpha} \pi \omega \lambda \varepsilon \varepsilon^{\prime} \alpha \varsigma$ "points to character rather than destiny. The expression means that he was characterized by 'lostness,' not that he was predestined to be 'lost'."' James Brownson would disagree with both proposals. According to him, ó viòs $\tau \tilde{\eta} \varsigma \dot{\alpha} \pi \omega \lambda \varepsilon i ́ \alpha \varsigma$ should not be translated as a genitive of purpose ("son destined for destruction") or as an adjectival genitive ("destroying son") but rather as a genitive of origin ("son of destruction/perdition"). ${ }^{16}$ In his opinion, the noun $\alpha \dot{\alpha} \omega \dot{\lambda} \varepsilon 1 \alpha$

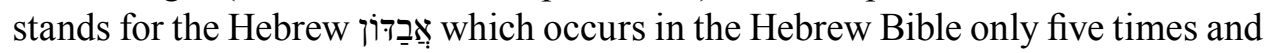
describes the place of destruction (Job 26:6), death (Job 28:22), total destruction (Job 31:12), or the realm of the dead (Ps 88:12; Prov 15:11). This noun is also used as a synonym of Sheol (Job 26:6; Prov 15:11) and personified death (Job 28:22). Based on these semantic correlations, Cornelius Bennema argued:

[T] he reference to Judas as "son of destruction/hell" corresponds to the earlier description of Judas as "devil" (6:70-71). The epithet may also evoke the image of the thief who comes to destroy in 10:10, since the word for "thief" occurs only in 10:1, 8, 10 and then again in 12:6 specifically with reference to Judas. Thus, Jesus' reference to Judas in 17:12 as "son of destruction" implies that Judas is an agent of the devil, in that he belongs to the devil and acts like him. Whether Judas was (pre)destined for destruction was probably not an issue for John. ${ }^{17}$

This close correlation between Judas and the devil found in the Fourth Gospel prompted Francis J. Moloney to advance an implausible hypothesis that "the son of perdition" in John 17:12 should be identified with Satan, not Judas, and

R.E. Brown, The Gospel According to John (XIII-XXI) (AB 29A; New York, NY: Doubleday 1970) 760 .

15 L. Morris, The Gospel according to John. Revised Edition (Grand Rapids, MI: Eerdmans 1995) 655-645. On the issue of Judas' predestination in relation to John 17:12, see L. Murray, "The Church Fathers and the Fall of Judas. Grace, Predestination and Free Will among Early Modern Catholic Biblical Commentaries", Augustiniana 65/3-4 (2015) 185-203.

16 J. Brownson, "Neutralising the Intimate Enemy: The Portrayal of Judas in the Fourth Gospel", $S B L$ 1992 Seminar Papers. One Hundred Twenty-Eighth Annual Meeting, November 21-24, 1992, The San Francisco Hilton, San Francisco, California (ed. E.H. Lovering) (SBL.SPS 31; Atlanta, GA: Scholars Press 1992) 52. F.W. Denker, "The vió 94, argues that there is no need to think of Hebraism (Semitism) or translation-Greek in the case of Jn 17:12. Referring to "the theory of analogical formations", he points out a few examples from the

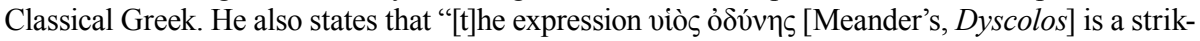
ing parallel to the one in John xvii. 12."

17 C. Bennema, Encountering Jesus. Character Studies in the Gospel of John. Second Edition (Minneapolis, MN: Fortress 2014) 237. Cf. also C. Bennema, "Judas (the Betrayer): The Black Sheep of the Family", Character Studies in the Fourth Gospel. Narrative Approach to Seventy Figures in John (ed. S.A. Hunt - D.F. Tolmie - R. Zimmermann) (Grand Rapids, MI: Eerdmans 2016) 366. 
that Judas is included in the "I did not lose one" in 17:12 and 18:9. ${ }^{18}$ As Francis Moloney puts it: "this Gospel makes no final judgment upon the disciple Judas. However bad his performance, he has now been given into the care of the Father whose remarkable love has been revealed by Jesus (cf. 17:11-12)." ${ }^{19}$ This view was criticized by those who studied the wholistic presentation of Judas as a character in the Fourth Gospel ${ }^{20}$. While Judas is indeed possessed by a demon, this fact does not mean that his person (with all his faculties, such as free will, decisionmaking, performing actions) disappears from the narrative, leaving room only for Satan. Most importantly, however, following the logic of Jesus' prayer in $17: 12$, which is concerned entirely with Jesus' disciples, it is difficult to imagine Jesus' talking about Satan as the one whom Jesus could not watched over and that was given to Jesus by the Father.

In what follows, we will present the main hypotheses concerning the scriptural referent of $\dot{\eta} \gamma \rho \alpha \varphi \eta$ in John 17:12 with regard to the figure of Judas, described as "the son of perdition". The exposition of the biblical and extrabiblical referents to the Johannine $\dot{\eta} \gamma \rho \alpha \varphi \eta$ will follow the canonical order.

\subsection{Genesis $49: 17$}

Jean Daniélou proposed looking to the Book of Genesis as the referent to the noun $\dot{\eta} \gamma \rho \alpha \varphi \eta$ in John 17:12. ${ }^{21}$ In his opinion the apocalyptic and eschatological overtone of the title ó viòs $\tau \tilde{\eta} \varsigma \hat{\alpha} \pi \omega \lambda$ eías found in 2 Thess 2:3 and John 17:12 is undeniable. He contends that the Johannine Judas denoted by this title is an anticipation of the Antichrist (in view of the parallel to 2 Thess 2:3) and an instrument of the devil (in view of the Johannine characterization of Judas as $\delta 1 \alpha$ $\beta 0 \lambda$ o in 6:70; cf. 13:2.27).22 As J. Daniélou observes, the same role was ascribed by the Testaments of the Twelve Patriarchs to the offspring of Dan, one of the twelve sons of James. Just before his death, Dan announces to his sons their apostasy

18 See Moloney, The Gospel of John, 467-468 and 483-484.

19 Moloney, The Gospel of John, 483-384.

20 See Bennema, Encountering Jesus, 236 and 240, note 35. W.M. Wright, "Greco-Roman Character Typing and the Presentation of Judas in the Fourth Gospel", $C B Q 71$ (2009) 559: "I would argue that John has passed judgment on Judas even before he directly appears in the Gospel narrative. Whereas Judas appears as a villain in each of the other canonical Gospels, John seized every opportunity to portray Judas as consistently vicious and wicked. Judas undergoes no real character development in the Fourth Gospel. Whenever Judas speaks, he lies. Whenever he acts, he does something shameful, whether it is thievery, disloyalty, or hypocrisy. Every single time that Judas appears or is mentioned in the Fourth Gospel, he is said to be the one who betrays Jesus $(6: 64,71$; $12: 4 ; 13: 2,11,21 ; 18,2,5 ; 21: 20)$. His role as the unfaithful disciple who hands Jesus over to his death is what defines Judas as a character in the Fourth Gospel."

21 Daniélou, "Le fils de perdition", 187-189.

22 Daniélou, "Le fils de perdition", 188: "Juda apparaît donc chez Jean comme une anticipation de l'Antéchrist (...) L'expression « fils de perditon » signifie donc « instrument du diable »." 
in the last days (Testament of Dan 5:4) and their satanic provenience (5:6) ${ }^{23} \mathrm{In}$ J. Daniélou's opinion, this document predates the New Testament. ${ }^{24}$ A similar tradition was known to the first Church Fathers, Irenaeus of Lyon ${ }^{25}$ and Hippolytus of Rome, ${ }^{26}$ for whom Antichrist, the son of the devil, came from Dan's progeny.

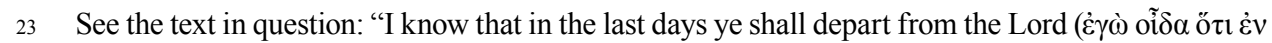

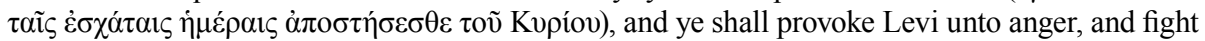
against Judah; but ye shall not prevail against them. For an angel of the Lord shall guide them both; for by them shall Israel stand. And whensoever ye depart from the Lord, ye shall walk in all evil and work the abominations of the Gentiles, going a-whoring after women of the lawless ones, while with all wickedness the spirits of wickedness work in you. For I have read in the book of Enoch, the

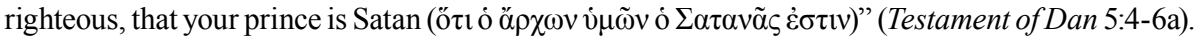
After R.H. Charles (ed.), The Greek Versions of the Testaments of the Twelve Patriarchs (Oxford: Clarendon 1908) 137; R.H. Charles (ed.), The Testaments of the Twelve Patriarchs (London: Clarendon 1908) 128-129. In fact, the document does not speak explicitly of the Satanic fatherhood but of the ruling power exercised by the Satan over Dan's generation (cf. the term ó ö $\rho \chi \omega v$ ).

24 There is still no agreement on which precise period this work should be dated to. The opinions, however, vary from the 2nd century BC (the Aramaic version of the Testament of Levi was known in Qumran) to the 1st century AD. According to M. de Jonge, The Testaments of the Twelve Patriarchs received its present form as a result of a Christian redaction dating back to the 2nd century AD. Cf. M. de Jonge, Jewish Eschatology, Early Christian Christology and the Testaments of the Twelve Patriarchs. Collected Essays (NT.S 56; Leiden: Brill 1991) 147-163. However, even if the Christian redaction or composition is acknowledged, it seems rather improbable to find the origins of the concept of Dan's sons as Satan's offspring in the New Testament (much less in John 17:12 where there is no mention of Dan's name or generation at all).

25 Irenaeus (Adversus Haereses V, 30, 2), quoting Jer 8:16, states that this passage speaks of the provenience of the Antichrist from the tribe of Dan: "he [Jeremiah] even indicates the tribe from which he shall come, where he says, We shall hear the voice of his swift horses from Dan; the whole earth shall be moved by the voice of the neighing of his galloping horses: he shall also come and devour the earth, and the fullness thereof, the city also, and they that dwell therein. This, too, is the reason that this tribe is not reckoned in the Apocalypse along with those which are saved". Indeed, in Rev 7:5-8 there is no mention of Dan among the twelve tribes of Israel. Dan is replaced by Manasseh, Joseph's son. It is interesting that only one manuscript (1854) replaces $\Gamma \alpha ́ \delta$ with $\Delta \alpha ́ v$ in $\operatorname{Rev} 7: 5$;

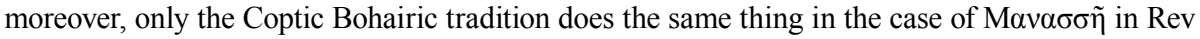
7:6. It is a proof of clear unanimity. Can it also be regarded as proof that the ancient scribes knew the aforementioned apocalyptic tradition concerning the condemnation of Dan? More on the absence of Dan in Rev 7:5-8 in B. Congemi Trolla, "L'assenza della tribù di Dan nell'Apocalisse canonica (7,5-8) alla luce delle tradizioni sul patriarca Dan e sui suoi discendenti", Cristianesimi nell'antichità: fonti, istituzioni, ideologie a confronto (ed. A. D'Anna - C. Zamagni) (Spudasmata 117; Hildesheim et al.: G. Olms 2007) 39-58.

26 Hippolytus (Antichrist, 14) writes, 'Dan', he [Moses] says, 'is a lion's whelp' and in naming the tribe of Dan, he declared clearly the tribe from which Antichrist is destined to spring. For as Christ

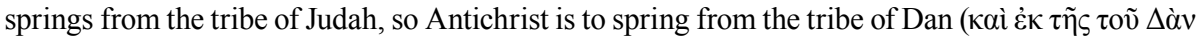

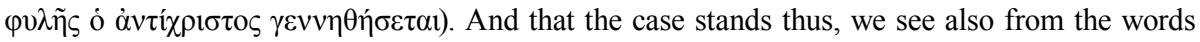
of Jacob: 'Let Dan be a serpent, lying upon the ground, biting the horse's heel.' What, then, is meant by the serpent but Antichrist, that deceiver who is mentioned in Genesis, who deceived Eve and supplanted Adam?". And he (Antichrist, 15) continues, "That it is in reality out of the tribe of

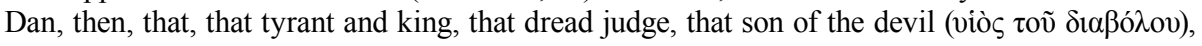
is destined to spring and arise, the prophet testifies when he says 'Dan shall judge his people, as (he is) also one tribe in Israel' (Gen 49:16). But some one may say that this refers to Samson, who sprang from the tribe of Dan, and judged the people twenty years. Well, the prophecy had its partial fulfilment in Samson, but its complete fulfilment is reserved for Antichrist". The Greek text after 
Moreover, Hippolytus states that the same snake, a symbol of Gad (Gen 49:17), tempted the Apostles and eventually seized Judas (Benediction of James, 220). In this way, in early Christian thought (at least for Hippolytus) Dan became the OT prefiguration of Judas as an anticipation of the Antichrist and an instrument of the devil. ${ }^{27}$ According to J. Daniélou, the author(s) of Jn 17:12 and Rev 7:5-8 had to be conversant with the same apocalyptic Jewish tradition concerning the identification of the Antichrist with Dan, the son of the devil. Given this perspective, J. Daniélou declares that $\dot{\eta} \gamma \rho \alpha \varphi \eta$ in Jn 17:12 refers to Gen 49:17 which is interpreted in the apocalyptic manner. To prove that, he also points out a striking parallel between the figures of Judas and Dan: (1) both are one of the twelve, (2) both are the anticipation of the Antichrist, and (3) both are an embodiment of the devil (cf. Jn 13:27).

How is one to assess Daniélou's proposal of the deliberate allusion to Gen 49:17 by the author of the Fourth Gospel? The idea of the Antichrist is undoubtedly present in the intertestamental period literature, however without the detail of his provenience from Dan's tribe. Literally, Testament of Dan only speaks of Satan as the father of Dan's offspring and his rebellion against Levi. ${ }^{28}$ Thus, the idea of Dan's Antichrist appears for the first time among the Christian writers (Irenaeus and Hippolytus). ${ }^{29}$ The only evidence that this idea might have been well known at the time of the fourth evangelist lies in the absence of the name of Dan among the twelve tribes which provide the 144 thousand sealed in Rev 7:5-8. J. Daniélou observes that the name of Dan is not mentioned because the author of the book of Revelation was conversant with the tradition that the Antichrist

H. Achelis (ed.), Hippolytus Werke, I/2: Hippolyt's kleinere exegetische und homiletische Schriften (Die griechischen Christlichen Schriftsteller der ersten drei Jahrhunderte; Leipzig: J.C. Hinrichs 1897) 11.

27 Daniélou, "Le fils de perdition", 188. In Daniélou's opinion when Hippolytus explicitly states that Dan prefigures Judas he only makes explicit a well-known idea in the Johannine milieu.

28 G.W. Lorein, The Antichrist Theme in the Intertestamental Period (LSTS - JSPS 44; London: Sheffield Academic Press 2003) 113-117.

29 C.E. Hill, "Antichrist from the Tribe of Dan", JTS 46 (1995) 99-117, suggests that the tradition about the Antichrist from the tribe of Dan may be quite old even though it first appears in Irenaeus and Hippolytus. Contra D.E. Aune, Revelation 6-16 (WBC 52B; Nashville, TN: Thomas Nelson 1998) 463 , who argues that "the tradition is not found in any Jewish sources and cannot therefore be confidently thought to be pre-Christian." Indeed, the case cannot be settled with any certitude. There are traces of a negative reputation of Dan in the OT (Gen 49:17; Judg 18:30; Jer 8:16) as well as in early Judaism (e.g. in Vitae Proph. 3:17-20, the prophet Ezekiel pronounces judgment on the tribes of Dan and Gad for persecuting those who kept the law. At the same time, however, "Dan was not blacklisted in early Judaism, for none of the many lists of the twelve tribes in early Jewish literature omits Dan (with the exception of Ps.-Philo Bib. Ant. 25:4, an accidental omission). Not only that, but there is a tradition that the mother of the Messiah would be a Danite (Gen. Rab. 97.9; ed. TheodorAlbeck): "This is the Messiah ben David who will arise from two tribes: his father from Judah and his mother from Dan" (Aune, Revelation, 462). 
hailed from the tribe of Dan. ${ }^{30}$ John, calling Judas "one of the twelve" (cf. Jn 6:7071), may have consciously alluded to this tradition. The proposal of J. Daniélou is ingenious, yet at the same time it is just as difficult to prove. The complicated web of interrelationships and cross-references seems to be rather suspect: from the Johannine son of perdition to the son of perdition of 2 Thess 2:3 and to the biblical notion of the Antichrist; from this Antichrist to the notion of Antichrist in Irenaeus and Hippolytus; then from their conviction of Dan as the origin of the Antichrist to the lack of Dan's name in the book of Revelation, as proof that the idea of the Antichrist from Dan's tribe was well known to John's Gospel; from this premise to the statement that John in 17:12 makes a deliberate reference to Genesis 49:17 which compares Dan to the serpent. In favour of Daniélou's thesis speaks the literary form of John 17, which imitates the farewell discourse found in Genesis 49. ${ }^{31}$ The main weakness of Daniélou's proposal is "the fact that the 'Scripture' proposed as that referred to in John 17:12 is not the actual text of Gen 49:17 at all, but an apocalyptic and extra-canonical interpretation of it." ${ }^{32}$ Moreover, from the viewpoint of the Johannine narrative itself, John's alleged reference to Genesis 49:16-17 does not seem very transparent or self-evident. In order to rightly apprehend Daniélou's proposal, perhaps one should possess a more thoroughgoing knowledge of its Jewish backgrounds, especially regarding the status of the tribe of Dan. At present, the whole picture lacks clarity.

\subsection{Psalm 41(40):10 in John 13:18}

The majority view of the present scholarship sends a reader to Jn 13:18 and the

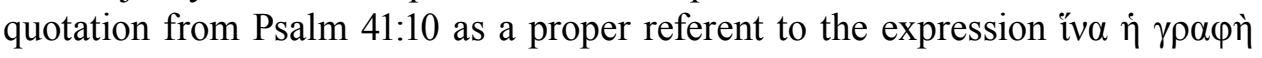
$\pi \lambda \eta \rho \omega \theta \tilde{\eta}$ in Jn 17:12. ${ }^{33}$ In all probability John in 13:18 preferred his own translation of the Hebrew text as opposed to the Septuagint that he normally used. ${ }^{34}$

30 C.R. Smith, "The Portrayal of the Church as the New Israel in the Names and Order of the Tribes in Revelation 7.5-8", JSNT 39 (1990) 115-116, thinks that the list of the twelve tribes had been partially assimilated to the list of twelve apostles in which, just as Matthias replaced the apostate Judas, so Dan has been replaced by Manasseh.

31 See E. Cortès, Los discursos de adiós de Gn 49 a Jn 13-17. Pistas para la historia de un género literario en la antigua literatura judia (Colectánea San Paciano 23; Barcelona: Herder 1976).

32 von Wahlde, "Judas", 172.

33 For instance, the commentaries by Barrett, Bernard, Brown, Bultmann, Carson, Hoskyns, Keener, Lagrange, Lindars, MacGregor, Morris, Sanders - Mastin, Schlatter, Schnackenburg, Simoens etc. See also J.R. Michaels, "Betrayal and the Betrayer: The Uses of Scripture in John 13.18-19", The Gospels and the Scriptures of Israel (ed. C.A. Evans - W.R. Stegner) (JSNTS 104 - SSEJC 3; Sheffield: Sheffield Academic Press 1994) 471: "Most commentators assume (probably correctly) that 'the Scripture' in mind here [Jn 17:12] is Ps. 41.10, the same Scripture quoted explicitly in 13.18."

34 M.J.J. Menken, Old Testament Quotations in the Fourth Gospel. Studies in Textual Form (CBET 15; Kampen: Pharos 1996) 125.136-138. With reference to the differences, Menken (p. 138) states:

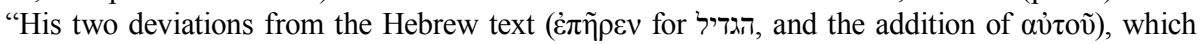


The juxtaposition of two versions of Psalm 41(40):10, found in Masoretic Text and LXX, as well as two Johannine passages, namely Jn 13:18 and 17:12, clearly shows that in the case of Jn 17:12 a textual connection can be established solely in reference to Jn 13:18. John 17:12 does not match textually the Masoretic and Greek versions of Ps 41(40):10. At first glance, it seems that there is nothing in common between these two Johannine texts except the references to the fulfilment of scripture (iv $\alpha \dot{\eta} \gamma \rho \alpha \varphi \eta \dot{\eta} \pi \lambda \eta \rho \omega \theta \tilde{\eta}$ repeated in both texts) and to Judas (in 13:18 by means of the quotation and in 17:12 by the phrase ó viò $\left.\varsigma \tilde{\eta} \varsigma \dot{\alpha} \pi \omega \lambda \varepsilon i i_{\varsigma}\right)$ ). On the other hand, however, one could argue that these similarities are entirely sufficient to make an unmistakable link between the passages. Hence the matter of context, and the function of the quotation within the Johannine context, turn out to be decisive.

The context of the scriptural reference in Jn 13:18 is the idea of choosing the disciples and Jesus' foreknowledge. Jesus was perfectly aware whom he had chosen. Having chosen Judas to become one of his closest disciples, Jesus had known in advance that Judas was going to betray him (13:11.21.27; cf. 6:64.7071). The message of the quotation is included in the idea that one of the loved ones will turn against Jesus. Hence the quotation provides a scriptural proof that Jesus' choice was right and legitimate. It was expected to happen in order to fulfil the Scripture.

In the case of 17:12 the reader is informed that the disciples were kept, watched over, preserved in the Father's name, and consequently not one disciple perished except "the son of perdition". Eventually, one reads that it happened so that the Scripture would be fulfilled. The question is what did happen? Logically, if the fulfilment of the Scripture refers to the figure of Judas, the scriptural passage should allude to the fact of not keeping and not watching over the disciple (or generally the disciples), namely, that one of them (or some or even all of them) had to perish. At the core of the concept would lay the loss (the double entrance of the same root $\dot{\alpha} \pi$ ó $\lambda \lambda v \mu 1-\dot{\alpha} \pi \omega \lambda \varepsilon i ́ \alpha \varsigma$ ) of one (or many) disciple(s).

At this point, one should ask: does Ps 41:10 match the aforementioned context of 17:12? The point of the psalmic verse is the rebellion of the trusted one, an intimate friend, and the threat which he represents. In fact, there is no mention of his perdition, death or any kind of a sad fate which he could meet. On the contrary, the psalm in verses 6-10 is an individual lament over the crisis. The psalmist being in a time of distress (presumably a sickness) sees in God the only possible source of help (vv. 5.11), while his foes (v. 6) and friends (v. 10) alike turned against him. In the context of Jn 13:18, Jesus, having taken the role of the psalmist, experiences a sad lot, whereas his good friend turns out to be against him.

make the text easier to understand, are due to the influence of 2 Sam. 18:28 - a passage analogous to Ps. 41:10 - either in Hebrew or in a corrected LXX version. John could not possibly use the LXX translation of Ps. 41(40):10, because it was at variance with his ideas about Jesus' omniscience." 
The point seems to be the betrayal by someone very close, a good friend. In fact, Rabbinic interpretation saw in Ps 41 a reflection of the David-Absalom affair and identified the traitor as Ahithophel (cf. 2 Sm 15-17). ${ }^{35}$ To that extent, Psalm 41 perfectly fits John chapter 13, as well as the larger context of Jesus' anxiety and passion (Jn 13-19). The message of the immediate context is also meaningful: Jesus, washing the feet of his disciples (13:1-12), offers a model for their reciprocal relations (13:15), which should be an expression of their mutual love (13:35) just as Jesus' action expressed his love (13:1.34). In 17:12 the stress is placed on showing something opposite: Jesus kept and preserved all. Jesus looked after his disciples. The clearest example of it is found in 18:8 when Jesus authoritatively

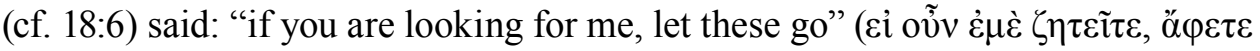

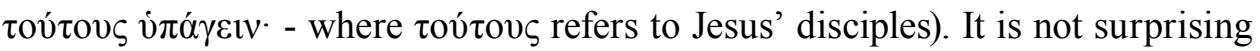
that the very next verse (18:9) is a close rendition of 17:12. The disciples are his "friends" until the end (the arrest in the garden). Jesus at this very difficult moment cares not about himself but about them.

To sum up, the phrase ivv $\alpha \dot{\eta} \gamma \rho \alpha \varphi \grave{\eta} \pi \lambda \eta \rho \omega \theta \tilde{\eta}$ in Jn 17:12, understood as a reference to Psalm 40:10, could only match the figure of Judas, one of the disciples (i.e., friends), but not the rest of the disciples mentioned in Jn 17:12 (they are still his friends). The context of 13:18 describes Judas as one of the friends who will deliver Jesus up. ${ }^{36}$ The quotation from Psalm 40:10 about the revolt of a friend

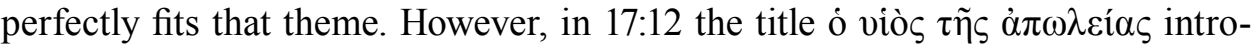
duces another characterization of Judas: an agent of the eschatological enemy of Jesus, an embodiment of the devil and Satan (whose time and reign is gone; cf. $12: 31 ; 16: 11$ ), someone doomed to failure and death. ${ }^{37}$ The message of Psalm 40:10 is obviously different, if not completely opposite. If 13:18 speaks of a friend, 17:12 points to an adversary. If the treachery of a friend is something unexpected and horrible, treason on the part of someone regarded as a natural enemy (an opponent par excellence) is something expected. One scriptural passage about the rebellious friend cannot explain these two different viewpoints. ${ }^{38}$

35 Let us note that according to Rashi "to eat my bread" means "to learn my teaching". The Talmud (Sanhedrin 2:106b-107a) reads: "At first David called Ahithophel his teacher, then his companion, and finally his disciple. (...) Finally his disciple - Yea, mine own familiar friend, in whom I trusted, which did eat of my bread, hath lifted up his heel against me."

36 Cf. $\pi \alpha \rho \alpha \delta i \delta \omega \mu \mathrm{u}$ in 13:2.11.21; also in $6: 64.71 ; 12: 4 ; 18: 2.5$; thus far, always in connection with Judas.

37 Sproston, "«The Scripture» in John 17:12", 26: "Jesus' choice of Judas is woven into an overall eschatological scheme; he is the figure which symbolises the final apostasy before Satan's downfall at the crucifixion." Cf. W.E. Sproston, "Satan in the Fourth Gospel", Studia Biblica 1978. II. Papers on the Gospels. Sixth International Congress on Biblical Studies, Oxford 3-7 April 1978 (ed. E.A. Livingstone) (JSNTS 2; Sheffield: Sheffield Academic Press 1980) 307-311, reprinted as W.E.S. North, "Judas Iscariot and Satan in the Fourth Gospel", A Journey Round John. Tradition, Interpretation and Context in the Fourth Gospel (LNTS 534; London et al:: Bloomsbury 2015) 21-24.

38 Moreover, regarding the formula of fulfilment in 13:18, it seems that the fulfilment of the Scripture was already in effect in chapter 13 . The quotation consists of two motifs: (1) partaking of the morsel 
Even if these two Johannine texts both speak of the disciples, they do it from different perspectives; their point of emphasis is evidently different. The text of 13:18a is in line with other similar passages where Judas and the disciples are mentioned as the chosen, and where Judas is already described as the one who will deliver Jesus up (6:70-71; 13:10-11; 13:18; 13:21-22). Wendy E. Sproston finds in all these texts the motif of "choosing and foreknowledge". The point is: the closest one, the chosen one, will betray. Verse 17:12 as well as its immediate context lacks completely any mention of the theme of Jesus' choice of his disciples, or of Judas and his betrayal. The thought is wholly concentrated on the notion of giving; the disciples are given by the Father to the Son. W.E. Sproston calls this motif the "unassailability" theme and one can easily detect it in $3: 16 ; 6: 39$; 10:28 and 18:9 by the use of the same vocabulary. The point is: the closest ones are kept, watched and do not perish. The mention of Judas in 17:12 seems to be rather a reminder for the reader of the notable exception to the "unassailability" rule..$^{39}$ There is no verbal reference to the largely understood theme of "choosing and foreknowledge". W.E. Sproston, rejecting the semantics of $\dot{\eta} \gamma \rho \alpha \varphi \eta$ in 17:12 as the reference to Ps 41:10 quoted in Jn 13:18, argues: "For the evangelist to make a reference to an earlier text giving no verbal hint of its wording or context would be out of character with his usual explicit style of cross-referencing (see, for example, 4:46; $4: 53$ cf. 4:50; 11:2, 37; 12:1; 18:9, 32)". ${ }^{40}$ To sum up, the reference to Ps 41:10, found in Jn 13:18, seems implausible due to the lack of contextual agreement between Jn 13:18 and 17:12.

\subsection{Psalms 69 and 109 in Acts $1: 20$}

It is interesting to note that Peter, referring to the tragic lot of Judas in Acts 1:16, emphasized the necessity of the fulfilment of the Scripture ( $\varepsilon \delta \varepsilon 1 \pi \lambda \eta \rho \omega \theta \tilde{\eta} v \alpha \iota \tau \eta$ $\gamma \rho \alpha \varphi \eta v$ ) which the Holy Spirit foretold by the mouth of David. It could be that same necessity that is being expressed in John 17:12 by iv $\alpha \dot{\eta} \gamma \rho \alpha \varphi \grave{\eta} \pi \lambda \eta \rho \omega \theta \tilde{\eta}$. Whereas the first quotation offered by Peter on this occasion indeed speaks of the miserable fate of Judas ("let his house become deserted, and let there be no one to live in it" - Ps 69[68]:26), the point of the second one ("let another take his office" - Ps 109[108]:8) shifts the focus to another problem: the election of the new apostle. The two passages are combined by Peter into one quotation and in

with Jesus and (2) the rebellion against him. Both points are fulfilled in 13:26-27 when Judas eats a piece of bread and Satan enters into him ( the rebellious one, becomes an adversary of Jesus, the rebellious one. No doubt the actual physical fulfilment of the second point happened in the garden when Judas delivered Jesus up, however this act is only an effect of the previous decision.

39 Sproston, "«The Scripture» in John 17:12", 26-28.

40 Sproston, “«The Scripture» in John 17:12”, 24. 
this way they both serve the same aim, namely the legitimization of the election of Matthias. Thus this combined quote, found in Acts 1:20, cannot serve as a referent for $\dot{\eta} \gamma \rho \alpha \varphi \eta$ in John 17:12.41

\subsection{Proverbs $24: 22$}

The exact wording, viò $\varsigma \dot{\alpha} \pi \omega \lambda \varepsilon i ́ \alpha \varsigma$, is found in a Greek, five-verse supplement at the end of Prov 24:22 (LXX):

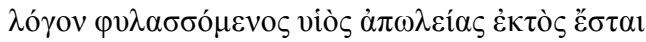

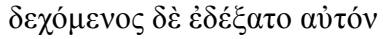

"A son who keeps the word shall escape [lit. will be outside of] the destruction;

for the one who is receiving has received it [for such a one has fully received it]."

The LXX addition presents a son, the typical addressee of the book (cf. Prov 1-9 and 24:1.13.21), who is warned about the wrath of a king. Syntactically, however, the genitive $\alpha \pi \omega \lambda \varepsilon i$ í does not refer to the subject (viós), but to the preposition $\dot{\varepsilon} \kappa \tau$ ó $\varsigma$ which demands the genitive. Moreover, the positive tenor of the whole sentence is exactly opposite to what one would expect. Thus the reference to Judas is impossible. Nonetheless, Edwin D. Freed, probably based on the mistake in translation, speculated about the possibility of this passage as a possible parallel to Jn 17:12.42

\subsection{Isaiah $34: 5 ; 57: 4$ and Ben Sira $16: 9 ; 46: 6$}

Antony T. Hanson states that there are many correspondences between the Johannine title ó viòs $\tau \tilde{\eta} \varsigma \dot{\alpha} \pi \omega \lambda \varepsilon i \alpha_{\varsigma}$ and the OT, and points to Is 34:5; 57:4 and Sira 16:9; $46: 6$ as being "nearer John's usage than the others". ${ }^{43}$ In Isaiah 34:5

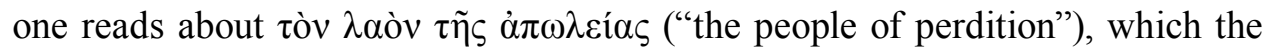

$41 \quad$ Ps 109 as a referent of $\dot{\eta} \gamma \rho \alpha \varphi \eta$ in John 17:12 was pointed out by Augustine, Tractatus, 107,7: Filius perditionis dictus est traditor Christi, perditioni praedestinatus, secundum Scripturam quae de illo in psalmo centesimo octavo maxime prophetatur (PL 35,1914). See also ;)E. Haenchen, John 2. A Commentary on the Gospel of John. Chapters 7-21 (Hermeneia; Philadelphia, PA: Fortress 1984) 154.

42 Freed, Old Testament Quotations, 97. Cf. also M. Davies, Rhetoric and Reference in the Fourth Gospel (JSNT.S 69; Sheffield: JSOT Press 1992) 268, with the totally wrong reading: "in Prov 24:22a 'son of destruction' is the indefinite form of the Johannine phrase'. R. Schnackenburg (John, 436-437) states: "This assumption by E. D. Freed (...) must be based on an error."

43 A.T. Hanson, The Prophetic Gospel. A Study of John and the Old Testament (Edinburgh: T \& T Clark 1991) 198. 
MT renders as חָּר ("people under my ban" or "people I have doomed"). Several chapters later, in Isaiah 57:4, one finds the phrase ov่ $\chi \dot{v} \mu \varepsilon \tilde{\iota} \varsigma \dot{\varepsilon} \sigma \tau \varepsilon \tau \dot{\varepsilon} \kappa v \alpha$ $\dot{\alpha} \pi \omega \lambda \varepsilon i^{\alpha} \alpha \varsigma$ ("Are you not children of perdition?"). This time the MT employs a different noun, עשָׁ, which means rebellion, revolt, offence, crime, transgression. ${ }^{44}$ Already in these two examples one sees that the phrase "son of perdition" can denote either the person's destiny (Is 34:5) or the person's character (Is 57:4). The former meaning is also found in the Greek version of Ben Sira 16:9 where one reads " $\theta \operatorname{vo} \varsigma \dot{\alpha} \pi \omega \lambda \varepsilon \varepsilon^{\prime} \alpha \varsigma$ ("the nation of perdition"). Its preserved Hebrew equivalent is as follows:

םרח יוג לע למח אלו

"he did not show compassion to a nation under the ban"45

The same Hebrew expression (גוי חרם) appears only one other time in Biblical Hebrew, namely in Ben Sira 46:6 $6^{46}$. The first aforementioned instance from Isaiah refers to Edom (as epitomizing the hostile nations that oppose God), the second to idolatrous Judeans (the inhabitants of Jerusalem). The expressions found in Ben Sira refer to the Sodomites (16:9) and the Canaanites (46:6). Thus the idea of perdition as the final destiny is applied to either foreign nations or idolaters. There is no doubt that idolatry and foreign nations (by means of their idolatry) were seen as something abominable. This context would perfectly fit the Johannine characterization of Judas as an incarnation of the devil.

\subsection{Zechariah 11:12-13 in Matthew 27:9-10}

Besides Acts 1:16, the only other place in the NT where Judas' death is mentioned is Matthew 27:5: "having gone away, he hanged himself". It happened just after Judas, having felt pangs of remorse for his betrayal, returned the thirty silver coins to the chief priests and the elders. They used it to buy the Potter's Field as a burial place for foreigners. The whole event is accompanied by a scriptural quotation introduced by the fulfillment formula: "Then what was spoken by Jeremiah the prophet was fulfilled ( $\dot{\varepsilon} \pi \lambda \eta \omega \dot{\theta \eta})$ ), saying: They took the thirty silver

\footnotetext{
44 Cf. HALOT 7790; BDB 833.

45 I. Lévi, The Hebrew Text of the Book of Ecclesiasticus (SSS 3; Leiden: Brill 1969) 25.

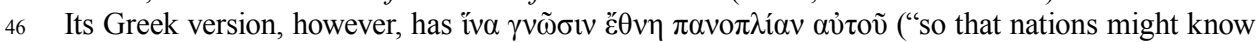
his armament"). One could ask whether a translator did not misread חרבו ("his sword") instead of the graphically similar חרם ("ban"), especially since the Aramaic version has כלהון עממא חרמא. Cf. חרם Re Smend, Die Weisheit des Jesus Sirach (Berlin: Reimer 1906) 441. Moreover, in place a Latin (or even Greek) translator could have read כחם ("their power") since Vulgate has potentiam eius here. Cf. I. Lévi, L’Ecclésiastique ou la Sagesse de Jésus, fils de Sira. Texte original hébreu (Bibliothèque de l'école des hautes études. Sciences religieuses 10; Paris: Leroux 1898) I, 112.
} 
coins, the price of the one whose price had been set by the sons of Israel and they gave them for the potter's field, as the Lord commanded me" (Mt 27:9-10). The quote is attributed to Jeremiah, although it looks rather as if it were taken from Zechariah 11:12-13. Aileen Guilding contends that the Johannine phrase kai

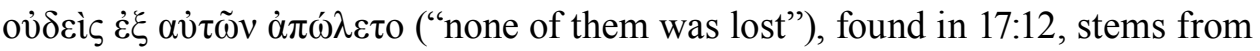

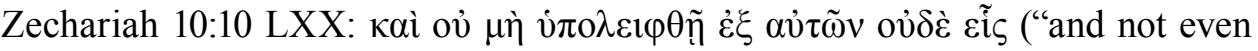
one of them shall be left behind"). ${ }^{47}$ Despite the presence in both texts the references to the fulfilment of Scripture (the same verb $\pi \lambda \eta \rho \cos ^{\prime} \omega$ ) and to the figure of Judas, as well as to the Book of Zechariah (in John's Gospel very hypothetically), the parallel does not allow connecting Judas' fall in John 17:12 with Zech 11:1213 quoted by Matthew. The point of the whole argument in Mt 27:9-10 (and Zech 11:12-13) is not Judas' death but the traitor's money. That being so, this prophetic text cannot serve as a referent to the semantics of $\gamma \rho \alpha \varphi \eta$ in Jn 17:12.48

\subsection{Psalms of Solomon}

The idea of the destruction of a sinner, expressed by the noun $\dot{\alpha} \pi \omega \dot{\lambda} \varepsilon \varepsilon \alpha$, occurs

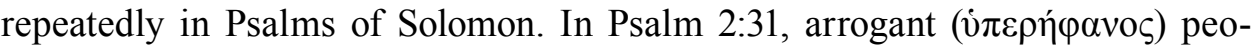
ple are put to sleep for everlasting destruction $(\dot{\alpha} \pi \hat{\omega} \lambda \varepsilon 1 \alpha)$ in dishonour, because they did not know God. Psalm 3:11 states that "the destruction of the sinner

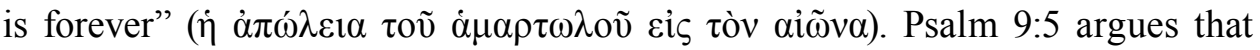
"the one who practices injustice is responsible for the destruction of his own

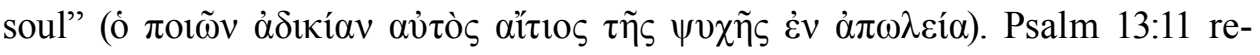
peats the idea that "sinners shall be taken away into destruction" ( $\dot{\alpha} \mu \alpha \rho \tau \omega \lambda$ oì

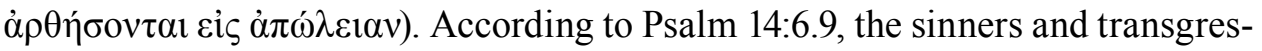

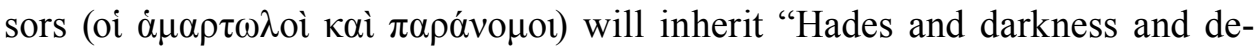

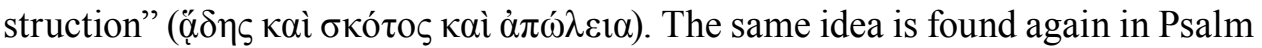
$15: 10$, where one reads that "the inheritance of sinners is destruction and dark-

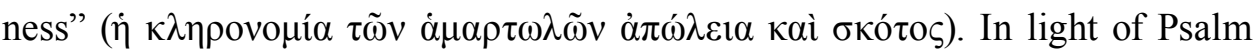
15:9, upon the forehead of sinners there is the mark of destruction ( $\tau$ ò $\sigma \eta \mu \varepsilon i ̃ o v$ $\left.\tau \tilde{\eta} \varsigma \dot{\alpha} \pi \omega \lambda \varepsilon \varepsilon^{\prime} \alpha \varsigma\right)$ and for that reason they will be overtaken and shall not escape the judgment of the Lord. Psalm 15:12 continues with the image of sinners that shall perish forever in the day of the Lord's judgment ( $\dot{\alpha} \pi \mathrm{o} \lambda \mathrm{ov} v \tau \alpha \mathrm{l} \dot{\alpha} \mu \alpha \rho \tau \omega \lambda \mathrm{o}$

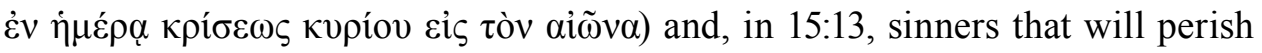

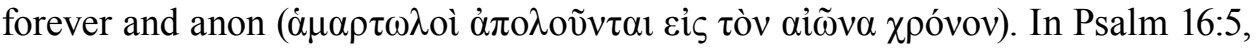

47 A. Guilding, The Fourth Gospel and Jewish Worship. A Study of the Relation of St. John's Gospel to the Ancient Jewish Lectionary System (London: Oxford University Press - Clarendon 1960),() 165.

48 These texts are pointed out as a referent of $\dot{\eta} \gamma \rho \alpha \varphi \eta$ in John 17:12 by M.C. Tenney, "John", The Expositor's Bible Commentary. IX. John and Acts (Grand Rapids, MI: Eerdmans 1981) 164; G.L. Borchert, John 12-21 (NAC 25B; Nashville, TN: Broadman \& Holman Publishers 2002) 198. 
a contrast is made between a saved one and the one who is counted "with sinners

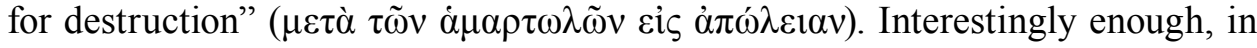
both John 17:12 and the passages above there is a contrast between a righteous one and a sinner or sinners. In all cases, the noun $\dot{\alpha} \pi \omega \dot{\omega} \lambda \varepsilon 1 \alpha$ and the verb $\dot{\alpha} \pi \hat{\lambda} \lambda \lambda \nu \mu 1$ describes the end of a sinner. Both the Fourth Gospel and Psalms of Solomon use the symbolism of darkness and light to describe sinners/unbelievers and righteous/believers. For instance, in Psalm 3:11-12, the destruction of the sinner ( $\dot{\eta}$ $\dot{\alpha} \pi \omega \dot{\lambda} \varepsilon 1 \alpha \tau \sigma \tilde{v} \dot{\alpha} \mu \alpha \rho \tau \omega \lambda \mathrm{ov})$, which will last forever, is juxtaposed with the eternal

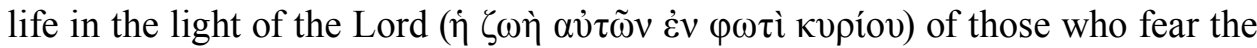
Lord. The concept of the Lord's judgment is one of the constantly recurring ideas in the Psalms. John also talks about judgment through the lenses of his realized eschatology $(5: 30 ; 9: 39 ; 12: 31)$. To sum up, there is a cluster of ideas which are common both to the Fourth Gospel and to the Psalms of Solomon, similarities that can stem from the common theological milieu of late Second Temple Judaism. In the case of John 17:12, the only point of contact is limited to the idea of destruction of a sinner. In any event, the phenomenon of direct borrowing is impossible to prove.

\subsection{Jubilees}

In the Book of Jubilees there is a prayer of Noah, who thanks God for being saved from the flood waters and not perishing like the people meant for destruction (10:3). In the latter part of the book, anyone who is not circumcised "does not belong to the people of the pact which the Lord made with Abraham but to the people (meant for) destruction" (15:26). An uncircumcised person is meant "for destruction, for being destroyed from the earth, and for being uprooted from the earth" $(15: 26){ }^{49}$ The parallel is not perfect, because Jubilees speaks of the "children" and John 17:12 mentions "the son". There is no Greek manuscript of this book, which was originally composed in the Hebrew language, so it is impossible to judge the possibility of any direct borrowing from Jubilees. The available citations and allusions to Jubilees from several Greek authors do not contain 10:3 and 15:26 ${ }^{50}$. Both Jubilees and John share the same terminology which, once again, can be explained by their common religious background within Second Temple Judaism ${ }^{51}$.

49 The translation from Ethiopic after J.C. Vanderkam, The Book of Jubilees (CSCO 511 - SAe 88; Lovanii: Peeters 1989) 92.

50 The same can be said about the Hebrew text of Jubilees found in fragmentary remains of 13 manuscripts of the book in the caves near Qumran. The list of Greek excerpts reflecting the lost Greek version of Jubilees is provided by J.C. Vanderkam, Jubilees, p. XIII-XIV. For Qumran texts, see his work, p. VII.

51 The Book of Jubilees was pointed as a parallel theological context for understanding the title o

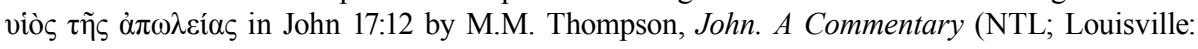




\subsection{Dead Sea Scrolls}

If one resorts, as some indeed do, ${ }^{52}$ to Qumran literature, then one should take into consideration the noun שָׁn, which generally denotes the sphere of evil, as opposed to the sphere of $\operatorname{good}^{53}$. In a few cases the noun is used to describe an individual: אבני השחת (CD 6:15), אנשי השחת (1QS 9:16.22) or אנשי שחת (1QS 10:19). ${ }^{54}$ Damascus Document (CD) in the passage 6:2-7:8 presents the terms of God's covenant with those faithful to him. Among those conditions is the command of separation "from the sons of the corruption" (מבני השחת) - 6:15) who are described as those who "steal from the poor, preying upon widows and murdering orphans" (6:16-17). ${ }^{55}$ Chaim Rabin notes that when the author describes a convert to the community, השב מדרכו הנשחתה "one who turns from his corrupt way" (CD 15:7), he makes reference to the title בני שחרת, the group to which the new convert had previously belonged. ${ }^{56}$ In another document, The Rule of the Community (1QS), a cosmic dualism dominates its theology. The human is torn by a universal struggle between two extremely powerful angels, the Angel of Light and the Angel of Darkness. Moreover, the human is either created into the

Westminster John Knox 2015) 353. She comments: "In every case [Sira 16:9; Jub. 10:3; 15:26] the idiom "children" or "people of destruction" refers to the wicked or disobedient, those outside the covenant. Judas has been "lost" to destruction because he has turned from following Jesus, like a branch that fails to bear fruit and so is "taken away" from the vine (15:2)." See also J.H. Bernard, Gospel according to St. John (ICC; Edinburgh: T \& T Clark 1928) II, 571; R. Fabris, Giovanni. Traduzione e commento. Seconda edizione riveduta e ampliata (Commenti biblici; Roma: Borla 2003) 663.

52 Sproston, "Satan in the Fourth Gospel", 309; North, "Judas Iscariot", 23; Hanson, Prophetic Gospel, 198; Klassen, Judas, 153.

53 The noun itself is beset with etymological ambiguity in BH. As related to the root "to sink down"), it denotes "pit", "trap", "grave" (BDB, 1001), whereas in relation to the root ("to go to ruin") it means "corruption", "destruction" (BDB, 1007).

54 Cf. J.H. Charlesworth et al., Graphic Concordance to the Dead Sea Scrolls (Tübingen: Mohr Siebeck - Louisville: Westminster John Knox 1991) 155.499-500. Cf. also מלאך השחת ("a messenger of the pit/corruption"- Blessingsb 4Q287 frg. 6, line 6), בליעל לשחת מלאך משטמה ("Belial for the pit [to corrupt], angel of enmity" - War Scrolle 4Q495 frg. 2, line 3).

55 Another passage, CD 13:14, is rather ambiguous. The manuscript reads לבני השחר, "sons of dawn", which denotes the Essenes or proselytes, rather than לבני השחת, "sons of the pit/corruption". Cf. J.M. Baumgarten, "The 'Sons of Dawn' in CDC 13,14-15 and the Ban on Commerce among the Essenes", Israel Exploration Journal 33 (1983) 81-85; J.H. Charlesworth et al. (ed.), The Dead Sea Scrolls. Hebrew, Aramaic, and Greek Texts with English Translations. II. Damascus Document, War Scroll, and Related Documents (Princeton Theological Seminary Dead Sea Scrolls Project 2; Tübingen: Mohr Siebeck - Louisville: Westminster John Knox 1995) 54-55, note 203. Contra F. García Martínez, The Dead Sea Scrolls Translated. The Qumran Texts in English (Leiden: Brill - Grand Rapids, MI: Eerdmans 21996) 43, who translates: "And none of those who have entered the covenant of God should either take anything from or give (anything) to the sons of the pit". Also Roland E. Murphy, "Šahat in the Qumran Literature", Biblica 39 (1958) 61, reads השחת here.

56 C. Rabin, The Zadokite Documents (London: Clarendon 1954) 24-25. According to Roland E. Murphy ("Šahat", 61-62), this passage alludes to Gen 6:12, where the moral corruption of mankind before the flood is recorded. 
realm of light (so-called "sons of light" - בני אור, "sons of truth" - בני אמת, or "sons of righteousness" - בני צדק) or the realm of darkness ("sons of darkness" - בני חושך, or "sons of deceit" - בני עול (בני (2) Among the latter group of individuals, which includes all people who do not belong to the community, the one called "a man of (the) corruption" is included (אנשי השחת - 1QS 9:16.22;58

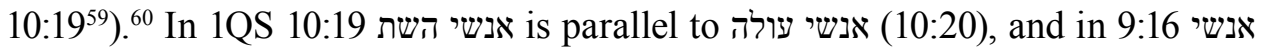
אנשי העול to (9:17). According to Roland E. Murphy, these parallel occurrences undeniably point to "moral corruption" rather than to "a pit" or "a grave" as the proper semantics of the noun שחת in the Qumran literature. ${ }^{61}$

It is almost a cliché to observe that the same type of dualism is present in John. In the Fourth Gospel there are at least two sets of dualistic images: (1) the children of light/darkness who do or walk in light/darkness, truth/falsehood (1:6$7 ; 2: 11 ; 3: 21 ; 8: 12 ; 9: 4-5 ; 11: 9-10 ; 12: 35-36.46)$; (2) the spatial imagery expressed by "from above" and "from below" (8:23), and "not from this world" and "from this world" $(8: 23 ; 15: 19 ; 17: 14-16 ; 18: 36) .{ }^{62}$ The question remains: does the figure

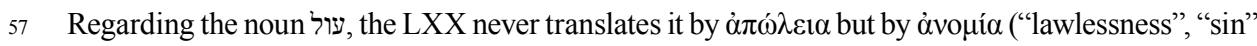
- Ps 53[52]:2; Ez 33:13.18), $\pi \lambda \eta \mu \mu \varepsilon ́ \lambda \eta \mu \alpha$ ("fault", "trespass" - Jer 2:5), $\pi \alpha \rho \alpha ́ \pi \tau \omega \mu \alpha$ ("false step",

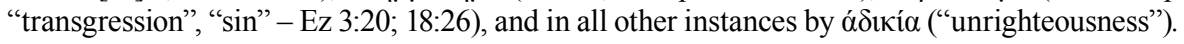

58 These occurrences are also preserved in 4Q258, frg. 3, col. 2; 4Q259 frg. 1, col. 3 [= only 1QS 9:16].

59 This text is also preserved in 4Q260 frg. 2.

60 There is also another expression found in the Dead Sea Scrolls, namely wrongdoing" (1QHa 14:30; 15:11), which is virtually synonymous and parallel to the aforementioned ones with שחשָָָׁדה ("indebtedness", "guilt") is never rendered in the LXX by $\alpha \dot{\alpha} \omega \dot{\lambda} \varepsilon 1 \alpha$.

61 Murphy, "Šahat", 61. According to R.E. Murphy, the title בני שחת "must certainly convey the meaning of corruption" (p. 62). Nevertheless in several passages שחת occurs as a synonym for the nether world (Sheol) - 1 QS 11:13; 1QH 5:6; 3:18.19; 8:28-29. Moreover שחת in figurative language (still with the sense of corruption) has its traps, snares and arrows (cf. 1QH 2:211 3:12.16.26-27). In 1QS 4:11-14 שח in allusion to Is 54:16 means "eternal corruption." See Murphy, "Šahat”, 62-65.

62 Cf. R. Bauckham, "The Qumran Community and the Gospel of John", The Dead Sea Scrolls Fifty Years after Their Discovery. Proceedings of the Jerusalem Congress, July 20-25, 1997 (ed. M. Galen - L.H. Schiffman - E. Tov - J.C. Vanderkam) (Jerusalem: Israel Exploration Society 2000) 106. At present, the scholarly viewpoints on the reciprocal relationship between the DSS and the Gospel of John vary, plus certain experts have shifted their stances over times. As to the issue of dualism, in the 1950s Raymond E. Brown concluded that DSS had influenced John's Gospel, but this process should be judged as indirect. See R.E. Brown, "The Qumran Scrolls and the Johannine Gospel and Epistles", CBQ 17 (1955) 403-419. This view is also reflected in his two-volume commentary. Yet less then fifty years later, near the end of his career, Brown concurred with the opinion that both Qumran and John have roots in the Hebrew Bible and "they have capitalized on relatively insignificant OT terms and have developed them in much the same way" R.E. Brown, An Introduction to the Gospel of John. Edited, Updated, Introduced, and Concluded by Francis J. Moloney (AYBRL; New York, NY et al.: Doubleday 2003) 142. R. Bauckham ("The Qumran Community", 111) has reached the same conclusion: "Characteristic terminology, dominant imagery, and theological significance all differ to such an extent as to make the influence of Qumran on the Fourth Gospel unlikely." He also notes that, of these two aforementioned sets of dualistic images, "the Qumran texts provide parallels only to the light/darkness opposition, which, of course, is found also in other Jewish texts" (Qumran Community, 106). In the same vein, after their examination of 1QS and the Fourth Gospel, A. Destro - M. Pesce, "Un confronto di sistemi. Il Vangelo di Giovanni 
of Judas inscribe itself in this dualistic pattern of John? The answer is positive when one notes in the Fourth Gospel the close identification of Judas with the figure of the devil/Satan $(6: 70 ; 13: 2.27)$ and the symbolic gesture of entering the darkness (13:30).

A.T. Hanson points out an interesting parallel to John 17:12 found in the Qumran literature, namely in $1 \mathrm{QHodayot}^{\mathrm{a}}\left(1 \mathrm{QH}^{\mathrm{a}}\right) 13: 25$ :

1QH v. 25 has the phrase "they go as talebearers to the sons of destruction". The phrase refers to the members of the author's own community who delate him to the Jewish authorities. The phrase of course denotes the authorities not the unfaithful disciples. It is surely a remarkable coincidence that in the same passage in the Hodayoth should occur both the scriptural reference to the unfaithful friend (see v. 23) and the phrase "sons of destruction". Was there in John's milieu some traditional connection between Psalm 41:9 and reprobation? Or is this an indication that John did have some sort of connection with Qumran in his cultural background? ${ }^{63}$

e la Regola della communità di Qumran", Atti del VIII Simposio de Efeso su S. Giovanni Apostolo (ed. L. Padovese) (Turchia: la Chiesa e la sua storia 15; Roma: Istituto francescano di spiritualità - Pontificio Ateneo Antoniano 2001) 103-104: "From the perspective of a systematic comparison, $[\ldots]$ the use of similar or identical concepts or terms has little meaning where the systemic purpose and function are different. [...] Expressions such as 'spirit', 'truth', 'do the truth', 'injustice', 'darkness', and 'light', all acquire a profoundly different meaning". For John Ashton, Understanding the Fourth Gospel (Oxford: Oxford University Press 1993) 205, any influence was out of the question, since the author of the Fourth Gospel was "an Essene", so consequently "this is the easiest and most convenient explanation of the dualism that is such a notable characteristic of his thought and marks off his Gospel from the other three." Ashton, however, has now radically changed his mind, as one can infer from the second edition of his work: "There is certainly an affinity between the Fourth Gospel and the Dead Sea Scrolls, but is not close enough to suggest a direct relationship, and in any case there is a depth and a deftness in the Gospel that surpasses anything in the Scrolls" See J. Ashton, Understanding the Fourth Gospel. Second Edition (Oxford: Oxford University Press 2007) 394. Ashton's earlier view is all of a piece with James H. Charlesworth's insights, who investigated at length the problem of dualism in both DSS and John's Gospel. J.H. Charlesworth, "A Critical Comparison of the Dualism in 1QS 3:13-4:26 and the "Dualism" Contained in the Gospel of John", John and the Dead Sea Scrolls (ed. J.H. Charlesworth) (New York, NY: Crossroad 1990) 76-106. He (p. 104) speaks of direct influence and states: "John probably borrowed some of his dualistic terminology and mythology from 1QS 3:13-4:26". In this study, Charlesworth (p. 103) lists eleven literary expressions shared by John and 1QS and concludes: "These similarities, however, are not close enough nor numerous enough to prove that John directly copied from 1QS. But on the other hand, they are much too close to conclude that John and 1QS merely evolved out of the same milieu. John may not have copied from 1QS but he was strongly influenced by the expressions and terminology of 1QS". In his newest treatment on the issue, he clarifies his point and unambiguously concludes that the ideas of the Rule of Community "directly influenced the Fourth Evangelist". J.H. Charlesworth, "Have the Dead Sea Scrolls Revolutionized Our Understanding of the New Testament?", The Dead Sea Scrolls Fifty Years after Their Discovery. Proceedings of the Jerusalem Congress, July 20-25, 1997 (ed. M. Galen - L.H. Schiffman - E. Tov - J.C. Vanderkam) (Jerusalem: Israel Exploration Society 2000) 127. For a helpful résumé and evaluation of the abovementioned views, see D.E. Aune, "Dualism in the Fourth Gospel and the Dead Sea Scrolls: A Reassessment of the Problem", Neotestamentica et Philonica. Studies in Honor of Peder Borgen (ed. D.E. Aune - T. Seland - J.H. Ulrichsen) (NT.S 106; Leiden: Brill 2003) 281-303; John, Qumran, and the Dead Sea Scrolls. Sixty Years of Discovery and Debate (ed. M.L. Coloe - T. Thatcher) (EJL 32; Atlanta, GA: Society of Biblical Literature 2011). 
In $1 \mathrm{QH}^{\mathrm{a}} 13: 22-23$ a person talks about being a cause for quarrel and argument to his friends or neighbours (Hebrew term רעי (לעוע) as well as a reason for challenge and grumbling to all his followers (לכול נועדי). It is indeed possible to compare this idea with Jesus' prediction of persecution which will befall Jesus' friends (Jn 15:18-21; 16:2). Most interestingly, the hymn talks about the betrayal of close ones, described by means of the reference to Ps 41:10. The Qumran text $\left(1 \mathrm{QH}^{\mathrm{a}} 13: 23-24\right)$ reads:

גם אוכלי לחמי עלי הגדילו עקב

"even those who eat my bread have raised their heel against me"

It is a direct allusion to Psalm 41:10, which reads:

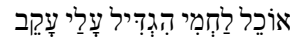

„one eating my bread have raised the heel against me”

In the immediate context of the reference to Ps 41:10, there is a description of those close ones who "mock with an unjust tongue", "are stubborn", "mutter round about", and finally "go slandering to the sons of destruction" (לכו רכיל "(לכ) " (לבני הוות) (1QH ${ }^{\mathrm{a}}$ 13:24-25). The parallel with the Johannine text is not perfect, although there is a conceptual similarity. In $1 \mathrm{QH}^{\mathrm{a}}$ a betrayer goes to "the sons of destruction", while in the Fourth Gospel the betrayer is "the son of destruction." Nevertheless, the Johannine "son of destruction" is undoubtedly an ally of the sons of the devil, as their father is the devil $(8,44)$. In fact, in $1 \mathrm{QH}^{\mathrm{a}} 13: 26$ the enemies are compared to Belial. In all probability A.T. Hanson's suggestion about "some sort of connection with Qumran in his [John's] cultural background" is probable, because the Essenes were present in many towns of Judah. However, it seems more justified to recognize the Hebrew Bible (Ps 41) as the common source for both $1 \mathrm{QH}^{\mathrm{a}}$ and John's Gospel. The apparent connection between the theme of unfaithful friend and "sons of destruction", found both in $1 \mathrm{QH}^{\mathrm{a}}$ and the Fourth Gospel, might be deemed coincidental. It could be rooted in the same cultural background of late Second Temple Judaism, in which an enemy was by definition called "a son of destruction." Any direct borrowing is improbable, as the Qumran text speaks about a group of people doomed to perdition, whereas Jn 17:12 speaks of a single individual. Moreover, the noun ("destruction"), found in the expression בני הוות "the sons of destruction/disaster", is never rendered in the LXX by $\alpha \dot{\alpha} \omega \dot{\lambda} \varepsilon 1 \alpha$.

To sum up, any direct lexical dependence between DSS and John is impossible to prove. As discussed, one can only speak of parallel theological visions which resulted in cognate terminology.

64 It does not even help to render בני in the singular. See Hanson, Prophetic Gospel, 198, note 42. 


\subsection{Thessalonians 2:3}

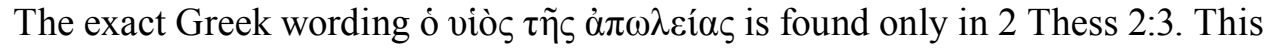

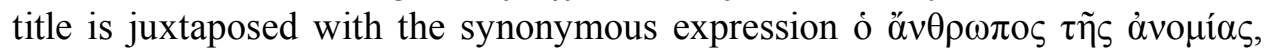
"the man of lawlessness", who stands in opposition to God. The context of the verse points to the second coming of Jesus. The linkage to the figure of Satan is striking: the arrival of "the son of perdition" will be done by Satan's working (2 Thess 2:9). Barnabas Lindars comments, "The passage in 2 Thessalonians implies that he [son of perdition] is not the Devil himself, but a sort of incarnation of evil, one in whom the Devil has absolute sway, and whose destruction represents the collapse of the Devil's final attempt to thwart God's will."'65

The semantics of the term $\dot{\alpha} \pi \hat{\lambda} \lambda \varepsilon 1 \alpha$ in the New Testament indeed points toward its eschatological dimension. In considering the occurrences of $\dot{\alpha} \pi \dot{\omega} \lambda \varepsilon 1 \alpha$ in the rest of the New Testament (18 times in total), its semantics varies: from the material waste of the costly perfumed oil in the alabaster vial (Matt 26:8; Mk 14:4) to the counterpart of life ( $\left.\zeta \eta^{\prime}\right)$ in Matt 7:13 and the (eternal) destruction of Simon, who wanted to buy the apostolic power issuing from the Holy Spirit (Acts 8:20). The latter meaning, which is connected with ultimate human ruin, also occurs in Rom 9:22; Ph 1:28; 3:19; 1 Ti 6:9; and Heb 10:39. The eschatological overtone is especially evident in the description of the beast doomed to destruction in Rev 17:8.11. Moreover, in A. Kretzer's opinion "the entire eschatological scenery and tension in 2 Peter" is characterized by the word $\alpha \dot{\alpha} \omega \lambda \varepsilon 1 \alpha$ which recurs 5 times (2 Pet 2:1bis; 2:3; 3:7.16): "deceivers as well as deceived are on the way to ruin, not least of all because of their false interpretation of Scripture (2 Pet 3:16)".66

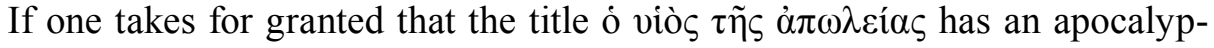
tic and eschatological dimension, ${ }^{67}$ then one could rightly ask whether Judas does not perhaps play a role comparable to the figure from 2 Thess 2:3. Indeed, C.K. Barrett suggests, "It seems probable that John saw in Judas this eschatological character who must appear before the manifestation of the glory of Christ (just as in 1 John 2:18.22; 4:3 heretical teachers are represented as Antichrist)" ${ }^{68}$ It is all of a piece with the Johannine notion of a realized eschatology. The final

65 B. Lindars, The Gospel of John (NCBC; London: Marshall, Morgan \& Scott 1972) 526.

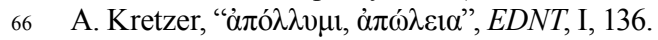

67 Reim, Studien, 45-46: "Dieser Begriff scheint aus apokalyptischer Literatur zu stammen"; Freed, Old Testament Quotations, 97-98; Daniélou, "Le fils de perdition", 188-189; Lindars, John, 526: "John very likely had [...] apocalyptic overtones in mind in using this title for Judas"; Sproston, "Satan in the Fourth Gospel", 309-311; Klassen, Judas, 153; G.R. Beasley-Murray, John. Second Edition (WBC 36; Dallas, TX: Word Books 1999) 299.

68 Barrett, John, 508. In a similar vein, J.S. Billings, "Judas Iscariot in the Fourth Gospel”, ET 51 (1939-40) 156, speculates, "may not the implication be that to St. John's mind the supernatural 'son of perdition' was not to be expected in the future, but had already appeared and had been incarnate in Judas Iscariot?" 
eschatological enemy was already acting and defeated during Jesus' life. In this context, Judas can be regarded as an agent of the eschatological enemy of Jesus. This view is congruent with the general characterization of Judas in the Fourth

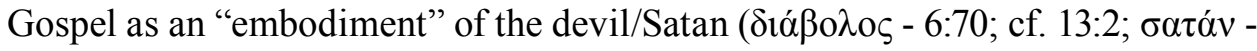
13:27). ${ }^{69}$ Rudolf Bultmann indeed noted that the title viò $\tau \tilde{\eta} \varsigma \alpha \dot{\alpha} \pi \omega \lambda \varepsilon$ cí ${ }^{\circ}$ describes Satan in Acta Pilati (known also as The Gospel of Nicodemus) II, 6(22),3 ("in-

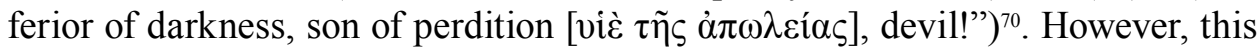
apocryphal text could have been influenced by the NT.

If one assumes that the lexeme $\dot{\alpha} \pi \hat{\omega} \lambda \varepsilon 1 \alpha$ alludes to the idea of the eschatological enemy of Jesus from 2 Thess 2:3, one could rightly ask whether the author of the Fourth Gospel knew of Second Thessalonians and, consequently, the idea of "the son of perdition" as a sign of Jesus" parousia. Since the majority view in current scholarship regards this epistle as the oldest writing of the New Testament corpus, an argument for their mutual influence is not implausible. Nevertheless, even if such dynamics existed, John expressed his own original thought in terms of his realised eschatology: the eschatological enemy of Christ is already present in Judas' person, and Jesus' parousia was manifested in his hour (passion and resurrection). ${ }^{71}$

One cannot accept the aforementioned view, however, without some qualifications. Undoubtedly, the context of Jn 17:12 articulates more the association of Judas with the disciples than with the devil. The verse, taken at face value, implies that the phrase "son of perdition" denotes that Judas is doomed to perdition as one of the twelve (consciously chosen by Jesus) and not due to his ontological nature ("the son of perdition" per se) as an embodiment of the evil one. ${ }^{72}$

69 More on this identification in A. Gagné, "Caractérisation des figures de Satan et de Judas dans le IVe Évangile: stratégie narrative et déploiement des intrigues de conflit", Science et esprit 55 (2003) 264: "[...] le quatrième évangile caractérise Judas Iscariote comme étant la manifestation terrestre de la figure de Satan. La caractérisation de ces deux figures johanniques, sert à construire trois sous-intrigues de conflit : Le Fils de l'homme versus le Prince de ce monde [Jn 12:31-33 - Jn 14:30; 18:2-5 - Jn 16:11], le Bon Berger versus le mercenaire-voleur [Jn 10] et Jésus versus Judas Iscariote [Jn 6:60-71 - Jn 12:4-6 - Jn 13:11.18.21-30]. Le tout est unifié par une intrigue démontrant que Jésus donne librement sa vie pour les siens." Cf. S. Bjerg, "Judas als Stellvertreter des Satans", Evangelische Theologie 52 (1992) 42-55.

70 R. Bultmann, The Gospel of John. A Commentary (Philadelphia, PA: Westminster 1971) 504. The translation of the passage in question in Acta Pilati in M.R. James, The Apocryphal New Testament. A Collection of Apocryphal Christian Literature in an English Translation (Oxford: Clarendon 1924) 131.

71 Brown, John, 760: "It is interesting that in Johannine realised eschatology the Son of Perdition appears during the ministry of Jesus, before his return to the Father". Lightfoot, John, 301: "In this gospel the day of the Lord is regarded as realized in the life, the work, and, above all, the death of Jesus Christ, St. John invites those who welcome his interpretation of the Gospel to see in Judas 'the man of sin, the son of perdition' [from 2 Thess 2:3]."

72 The same warning is expressed in K. Quast, Reading the Gospel of John. An Introduction (New York, NY: Paulist 1991) 115: "Some interpreters equate this phrase [son of perdition] with its use as a title for the eschatological antichrist in 2 Thessalonians 2:3. They then see this as evidence 


\subsection{Mark 14:1-11 and Internal Cross-Reference within John's Gospel}

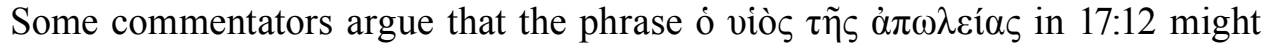
be prompted by a play on words which is present in the Johannine verse itself:

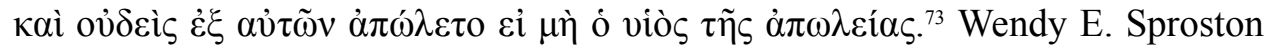
extends this idea by suggesting that there is good reason to assume a strong association in the Fourth Gospel between the figure of Judas and the idea of $\dot{\alpha} \pi \dot{\omega} \lambda \varepsilon 1 \alpha$. She states, "the connection between the figure of Judas and the notion of perdition/destruction is already a part of the evangelist's thinking before he reaches

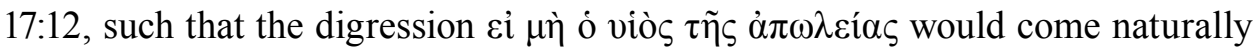
to his pen once he had used the verb á $\pi$ ó $\lambda \lambda \nu \mu \imath^{\prime \prime}{ }^{74}$ One could refer to at least two arguments to support this suggestion.

First, the Johannine description of the anointing of Jesus (Jn 12:1-8) generally follows the Markan pattern (Mk 14:1-11). Among the most distinctive features of John's version is his identification of Judas as the one who complains about not selling the perfume for the benefit of the poor, as well as his gloss about Judas' character as a thief, who used to steal the contributions $(12,6)$. At the locus where John introduces the figure of Judas, the Markan version raises the question: $\varepsilon i \varsigma \tau i$ '

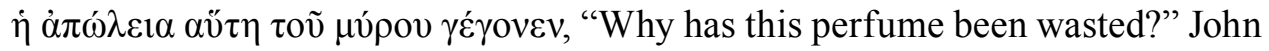
does not reproduce this question but, presumably knowing the Markan tradition, he introduces here Judas, the most probable speaker of this question. W.E. Sproston adds, "after all, what could be a more fitting irony than that the complaint about loss $(\dot{\alpha} \pi \dot{\omega} \lambda \varepsilon 1 \alpha)$ should be made by the 'son of loss'? Thus, at precisely the point where $\alpha \dot{\alpha} \omega \lambda \varepsilon 1 \alpha$ (in Mark, the only instance) appears in the tradition, John sees the opportunity to introduce Judas into his own narrative". ${ }^{75}$

Second, in the same Johannine narration of Jesus being anointed, Judas is characterised as a thief ( $\kappa \lambda \dot{\varepsilon} \pi \tau \eta \varsigma$ - 12:6). This kind of vilification of the future betrayer is found only in John. Mark does not employ this noun. Matthew and Luke use this term, but in relation to the sayings on treasures in heaven (Matt

of John's realized eschatology: Judas was the antichrist that marked the end of the age. However, a single reference in 2 Thessalonians cannot be conclusive. It is better to read John's phrase as a simple affirmation that Judas was destined to perish as part of the saving plan. This is not the first time John has tried to show that the choice of Judas was not an ignorant mistake (Jn 6:70-71; 12:4-8; 13:21-30)."

73 E.D. Freed (Old Testament Quotations, 98) states: "I also raise the question about how much the

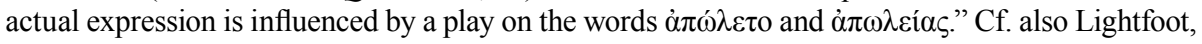
John, 301; J.N. Sanders - B.A. Mastin, A Commentary on the Gospel according to St John (London: Adam \& Charles Black 1968) 374; Lindars, John, 525.

74 Sproston, “《The Scripture» in John 17:12”, 28.

75 Sproston, "«The Scripture» in John 17:12", 29. The suggestion that the Markan version of the incident (14:1-11) was in John's mind when he mentioned Judas was for the first time prompted by J. Hastings - J.A. Selbie, A Dictionary of Christ and the Gospels (Edinburgh: T \& T Clark 1906) I, 909. Cf. also Bernard, John, 571. 
6:19.20; Lk 12:33) and the parabolic description of the unexpected second coming of the Lord (Matt 24:43; $\mathrm{Lk} 12: 39$ ). The verbal form ( $\kappa \lambda \varepsilon \dot{\varepsilon} \pi \tau \omega)$ is employed in the commandment of the Decalogue (Mk 10:19; Matt 19:18; Lk 18:20) and also with reference to the alleged stealing of Jesus' body from the tomb (Matt 27:64; 28:13). In John $\kappa \lambda \dot{\varepsilon} \pi \tau \eta \varsigma$ appears only in 12:6 and in the allegory on the Good Shepherd

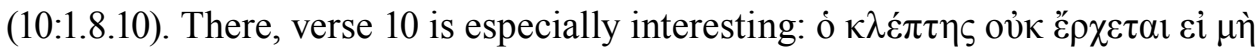

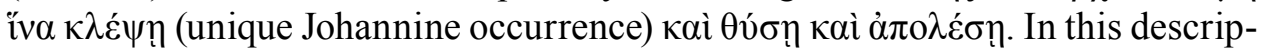
tion of the thief who comes to steal and kill and destroy, Raymond E. Brown recognises, "a general representative of darkness who is a rival to the Son". ${ }^{76}$ Wendy E. Sproston states that the verb $\alpha \dot{\alpha} \delta \hat{\lambda} \lambda \nu \mu 1$, which is applied only to the thief in this allegory, "is the basis for John's describing Judas as a thief in 12:6." As she observes, "this would give to John's ö $\tau 1 \kappa \lambda \dot{\varepsilon} \pi \tau \eta \varsigma \tilde{\eta} v$ a properly sinister ring". 77

Wendy Sproston's suggestion of a strong association in John's tradition between Judas and the idea of perdition/destruction can be summarized in two points. First, John introduces the figure of Judas in 12:6 at the point in the text where the earlier tradition, as reflected in Mark, features the term $\alpha \dot{\alpha} \omega \dot{\lambda} \varepsilon 1 \alpha$. Second, the description of Judas as a thief in Jn 12:6 stems from the association of $\dot{\alpha} \pi \hat{\lambda} \lambda \lambda v \mu \mathrm{r}$ with $\kappa \lambda \dot{\varepsilon} \pi \tau \eta \varsigma$ in Jn 10:10. In the case of 17:12, the main clause focuses on the theme of the unassailability of the disciples, often expressed in the negative, i.e. not perishing (using the same verb $\alpha$ ó $\lambda \lambda v \mu \mathrm{u}$ - cf. $3: 16 ; 6: 39 ; 10: 28 ; 18: 9$ ). It can naturally refer to $10: 28$ as a prefiguration of the fact (of preserving the disciples) which is stated as realized in 17:12. In 10:28 the verb $\alpha \pi \delta ́ \lambda \lambda v \mu \mathrm{t}$ is used in sharp contrast to its occurrence in 10:10, namely Jesus, the Good Shepherd, will take care of his sheep so they cannot perish (10:28), while the thief will steal, kill and destroy them (10:10). In 17:12 Jesus, in thanksgiving, states that he watched

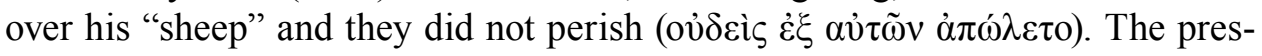
ence of $\dot{\alpha} \pi \hat{\lambda} \lambda \lambda v \mu \mathrm{r}$ in 17:12 would have been most likely inspired by the digression to Judas compared to a thief in the previous narrative.

\section{Reference to Jesus' disciples}

In view of the foregoing, any attempt to establish the precise OT referent to $\gamma \rho \alpha \varphi \eta$ in 17:12 with reference to Judas may seem a rather hopeless endeavour. There is, however, an alternative: the phrase ǐv $\alpha \dot{\eta} \gamma \rho \alpha \varphi \grave{\eta} \pi \lambda \eta \rho \omega \theta \tilde{\eta}$ refers not to the phrase

76 Brown, John, 394-395. For R.E. Brown, the reference to killing in 10:10 is connected with the description of the devil in 8:44.

77 Sproston, "«The Scripture» in John 17:12", 29. She (p. 30) adds, "the similarity between oư $\chi$ ö $\tau$ 1

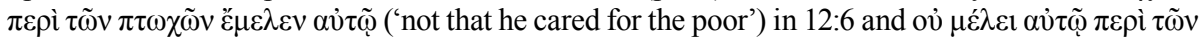
$\pi \rho \beta \beta \alpha ́ \tau \omega v$ ('he cares nothing for the sheep') in 10:13 is probably a further indicator that in 12:6 John had the 'good shepherd' material in mind." 


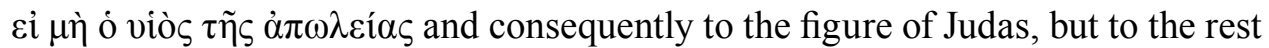
of the verse 17:12. Some commentators quoted above (Becker, Schnackenburg, Sproston) have already noticed that the sentence which speaks of Judas has the features of a superfluous gloss, a parenthetic digression from the main argument. This aspect of the text could well account for the above difficulties in establishing the exact semantics of $\gamma \rho \alpha \varphi \eta$ in the reference to Judas in the present context of 17:12. The "original" version of the text of John 17:12 might have contained the reference to the fulfilment of Scripture, but without mentioning Judas. This argument must remain, however, a hypothesis. If therefore the fulfilment of $\dot{\eta} \gamma \rho \alpha \varphi \eta$ indeed refers to the disciples, then one should look for either (1) an OT text which mentions the topics contained in 17:12 related to the disciples, that is, guarding

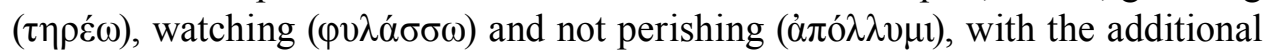
motif of the Father, a giver, and God's name, or (2) for a text found in the Fourth Gospel which mentions the same cluster of topics. In the latter case, the Fourth Gospel itself would be regarded by its author as the authoritative "Scripture."

\subsection{Old Testament Referent: Prov 22:24a}

As to the first possibility, one could enumerate several examples from the LXX

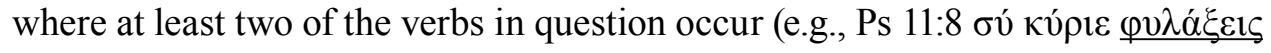

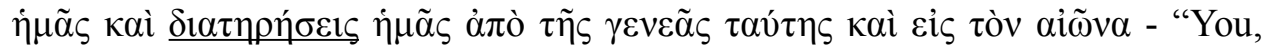
O Lord, you will protect us, and you will preserve us from this generation and forever"), not to mention single motifs (e.g., the entire Psalm 120 built on the idea of the Lord who keeps his people: кúpıऽ $\varphi v \lambda \alpha \dot{\xi} \xi \varepsilon \sigma \varepsilon)$. Aileen Guilding argued

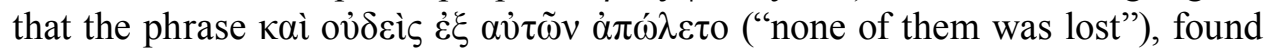

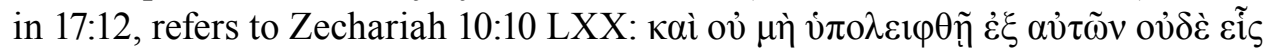
("and not even one of them shall be left behind"). ${ }^{78}$ Urban von Wahlde argued, however, that Prov 24:22a is the OT text that could be referred to in John 17:12. This text was already pointed out by Edwin Freed, as it was mentioned above, but with reference to Judas. Urban von Wahlde connects this OT passage with the idea of guarding the disciples from perdition. Thus the relevance of this text is twofold. It alludes explicitly to the disciples, who are guarded from perdition and it alludes implicitly to Judas, as the one who actually perished ${ }^{79}$.

There are a few arguments in favour of this thesis. First of all, the whole focus of Jesus' prayer, from 17:6 till 17:19, is on the disciples. It must be, however, clarified that Jesus prayed for the faithful eleven disciples, and not for the world (17:9) or for Judas, who is associated with the ruler of this world (cf. 12:31; 14:30; 16:11). The focus of Prov 24:22 is on the faithful son. In both texts then the emphasis is

78 Guilding, The Fourth Gospel and Jewish Worship, 165.

79 von Wahlde, “Judas", 174-175. 
on the positive examples. Second, the text of Prov 24:22 deals precisely with the obedient son who keeps the word of God and in this way avoids perdition. This

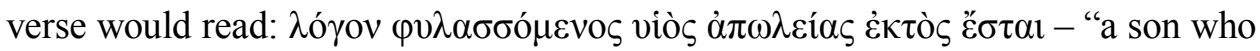
keeps the word will be far removed from destruction". There is then a conceptual parallel: being not lost thanks to keeping the word. Third, there is a correspondence between two texts in the idea of keeping the word. In the Proverbs text the son

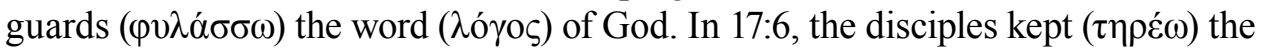
word ( $\lambda$ ó $\gamma \circ \varsigma)$ of the Father. Fourth, the somewhat awkward and peculiar repetition of words for keeping ( $\tau \eta \rho \varepsilon ́ \omega)$ and guarding $(\varphi v \lambda \alpha ́ \sigma \sigma \omega)$ in Jn 17:12 can be accounted for by the reference to the Proverbs text. The Johannine verb $\varphi v \lambda \alpha ́ \sigma \sigma \omega$ lacks an object or other modifier. Moreover, this term itself is rare in John and appears elsewhere only twice (Jn 12:25.47). Thus, U.C. von Wahlde concludes: "the fact that the word appears in Prov 24:22a suggests that perhaps it is introduced here by the Johannine author as a verbal echo of that verse." ${ }^{\text {80 }}$ Fifth, besides the word

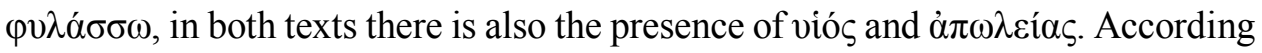
to U.C. von Wahlde, "[i]t seems fair to say then that we have not only a general correspondence in thought but also a verbal echo in what are arguably the three most significant words in the verse from Proverbs." ${ }^{\text {"81 }}$ Sixth, Edwin D. Freed argued that

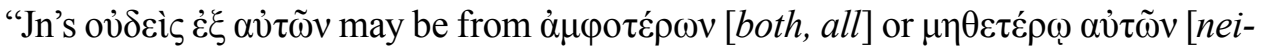
ther of them] of the preceding lines [Prov 24:22 and 24:21 respectively]." ${ }^{82}$ Seventh, for my part, I would point out the motif of "receiving the word" from God/king (Prov) and Father/Jesus (Jn), which is found in Prov 24:22a (

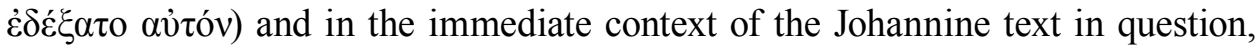

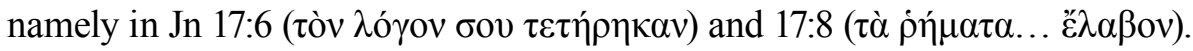

The problem with the above argumentation is that the subject of $\varphi v \lambda \alpha \sigma \sigma \sigma \omega$ in the Proverbs text is the son and not God or a king as one would expect, looking for a perfect parallel with the Johannine text. In other words, in Proverbs it is the son who "guards", being the subject of the action, while in John, it is Jesus who "guards." U.C. von Wahlde is aware of this difficulty and argues: "It may be that

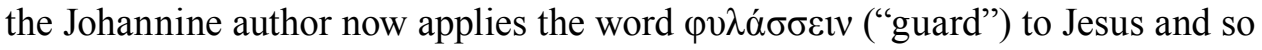
it may be his intention to show (through a kind of pesher exegesis) that it was really Jesus who preserved ( $\dot{\varepsilon} \varphi v ́ \lambda \alpha \xi \alpha)$ the disciples whom he had chosen." ${ }^{{ }^{83}} \mathrm{He}$ also counters this objection by pointing out that in the Fourth Gospel the responsibility for faithfulness of the disciples rests on three different factors: (1) the election of the disciples by Jesus $(6: 70 ; 13: 18 ; 15: 16.19)$, (2) the fact that the disciples are given by the Father $(6: 37.39 .65 ; 10: 29 ; 17: 2.6 .7 .9 .12 ; 18: 9)$, and (3) the disciples

80 von Wahlde, "Judas", 177. Cf. Freed, Old Testament Quotations, 97: “the word $\varphi v \lambda \alpha ́ \sigma \sigma \omega$ occurs in both passages."

81 von Wahlde, "Judas", 177. Cf. Freed, Old Testament Quotations, 97: "While the two words in Prov are not in the idiom Jn uses, they do occur together."

82 Freed, Old Testament Quotations, 97.

83 von Wahlde, "Judas", 177, note 24. 
themselves. All these three factors are combined and occur together in Jn 6:6465 and 17:1-11. In the case of Judas, it appears that he did not keep the word of the Father and so - on his own responsibility - could not be protected by Jesus ${ }^{84}$.

Urban von Wahlde also offers some rationale for the presence of the title "the son of perdition", as referred to Judas, based on the allusion to Prov 24:22a. First, the son, who keeps the word of God/king and is "outside destruction" is implicitly "contrasted with the son who does not keep the word of God and who will therefore be subject to perdition. This 'second' son will be, to identify him in

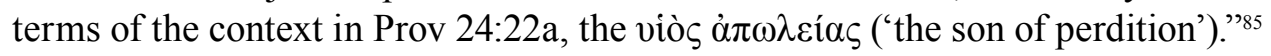
Second, given the precise word order of the Proverbs text, viòs à $\pi \omega \lambda \varepsilon i \alpha_{\alpha}$ (these two terms appearing side-by-side), it is easy to misread the text as referring to "the son of perdition" in a way that might facilitate the formation of the title. Obviously, in coining this phrase John could have been also influenced by Isa 34:5; 57:4 as well as 2 Thess 2:386.

To sum up, the advantage of U.C. von Wahlde's proposal is threefold. First, it explains the referent of $\dot{\eta} \gamma \rho \alpha \varphi \eta$ by means of a reference natural for John - as expected by the use of $\dot{\eta} \gamma \rho \alpha \varphi \eta$ - to the OT. Second, it elucidates a possible coinage of the phrase "the son of perdition" by reference to the same OT passage. Third, it focuses on the faithful disciples as the main point of interest of the whole immediate literary context of John 17:12. ${ }^{87}$ To our best knowledge (and surprise), von Wahlde's proposal has not found any followers among the authors of the recent commentaries on the Gospel of John.

\subsection{New Testament Referent: Jesus' Word Understood as the Scripture}

Wendy Sproston and Francis Moloney advanced a hypothesis that $\dot{\eta} \gamma \rho \alpha \varphi \eta ́$ in Jn 17:12 refers to Jesus' own words about his disciples not perishing. In order

84 The conclusion reached by von Wahlde ("Judas", 178), who states that Judas "did not keep the word of God and so was not protected from destruction."

85 von Wahlde, "Judas", 178.

86 von Wahlde, "Judas", 179. He concludes (p. 179) his analysis with an insightful remark: "I think there is a slight indication that perhaps even the author of Prov 24:22a was aware of the existence of such a title. (...) when the reader reads the verse for the first time, he/she can easily be startled by the statement which seems to say that the one who keeps the word of God is a son of perdition! But of course the author then clarifies this by the clever positive positioning of $\dot{\varepsilon} \kappa \tau$ ó the word of God is outside perdition. Was this a play on words and an attempt to get the reader's attention? There is of course no way to prove it, but the possibility is certainly there."

87 This interpretation of $\dot{\eta} \gamma \rho \alpha \varphi \eta$ in John 17:12 is also found in U.C. von Wahlde, The Gospel and Letters of John. II. Commentary on the Gospel of John (Eerdmans Critical Commentary; Grand Rapids, MI: Eerdmans 2010) 726 and 733; U.C. von Wahlde, The Gospel and Letters of John. III. Commentary on the Three Johannine Letters (Eerdmans Critical Commentary; Grand Rapids, MI: Eerdmans 2010) 311-313. 
to verify this proposition, it seems indispensable to look first at the vocabulary referring to the disciples in 17:12 as it occurs elsewhere in the Fourth Gospel, and then at Jesus' logion on his disciples "not perishing". A textual criticism will also be of help in this argumentation.

\subsubsection{The Vocabulary Referring to the Disciples in 17:12}

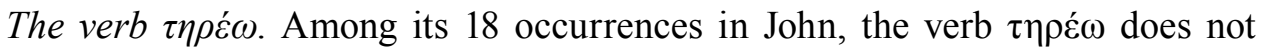
bear its literal meaning to guard (prisoners). In two cases its semantics point to the idea of preserving or keeping until some future time (e.g. the good wine in Cana-2:10; the perfumed oil - 12:7). Most frequently, in about half of the NT occurrences and the majority of the Johannine ones (13 times), it denotes the idea of keeping in the sense of following. In John's Gospel it refers to keeping Jesus'

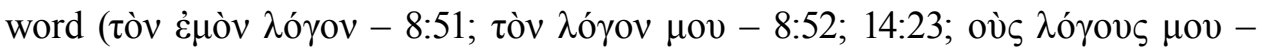

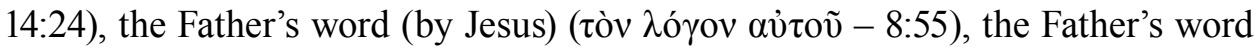
(by people/disciples) (17:6), the Sabbath (9:16), Jesus' commandments by his dis-

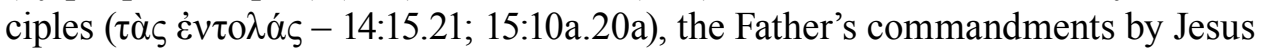

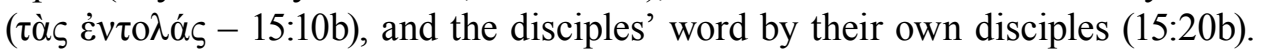
In 17:11.12 we encounter the notion of keeping Jesus' disciples in the Father's name (17:11.12), which expresses the idea of preserving or retaining their faith. ${ }^{88}$ This last idea alludes to keeping the unblemished condition of the disciples by preserving them from the evil one (17:15).

The verb $\varphi v \lambda \dot{\alpha} \sigma \sigma \omega$. The root $\varphi v \lambda \alpha \kappa$ conveys the idea of watching over, guarding.

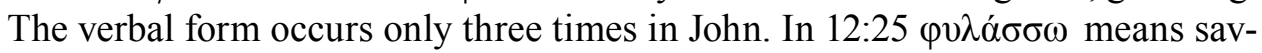
ing or preserving one's own life for eternity. A few verses later (12:47) it denotes not keeping Jesus' sayings, $\tau \grave{\alpha} \dot{\rho} \eta \mu \alpha \tau \alpha$. In the aforementioned occurrences the disciples were the subject; in 17:12 it is Jesus who watched over or guarded the disciples. This last instance has the closest affinity to the original etymology. In fact, two two verbs $\tau \eta \rho \varepsilon ́ \omega$ and $\varphi v \lambda \alpha ́ \sigma \sigma \omega$ are synonyms (cf. Matt 19:17.20); a difference is mostly achieved by the alteration of tense. ${ }^{89}$ In LXX we see it clearly in

88 In 17:11.12 the noun obvo $\mu \alpha$ is referred to in the sense of the revelation of God in the Son. R. Schnackenburg (John, 181) explains: "It was indeed an inner revelation of the reality of God, an introduction into the sphere of God and a communication of the love and joy of God from which Jesus himself lived."

89 Although $\varphi v \lambda \alpha ́ \sigma \sigma \omega \omega$ can have a much stronger meaning, see Sanders - Mastin, John, 373. B.F. Westcott, The Gospel according to St John. The Authorized Version with Introduction and Notes (London: John Murray 1892) 243, states: "The difference between the verbs themselves appears to be that 'kept' ( $\tau \rho \rho \tilde{i v})$ expresses the careful regard and observance of that which is looked at as without (e.g. Matt. 28:36), while 'guarded' ( $\varphi v \lambda \alpha ́ \sigma \sigma \varepsilon v v)$ describes the protection of something held as it were within a line of defence from eternal assaults." The imperfect غ̇ंท́ always watching" or "keeping my eye on" implies the continually watchful care of Jesus. The 
the Book of Proverbs $(2: 11 ; 8: 34 ; 13: 3 ; 16: 17 ; 19: 16 ; 25: 10$; cf. also Wis 10:5; Dan 9:4). They translate alternately either שצר or. The interpreter of LXX used both ( $\tau \eta \rho \varepsilon ́ \omega$ and $\varphi v \lambda \alpha ́ \sigma \sigma \omega)$ to translate two instances of the same Hebrew verb, e.g., שמר in Prov 8:34; 19:16.

The verb $\dot{\alpha} \pi \delta ́ \lambda \lambda v \mu l$. It occurs 10 times in John. In 3:16; 6:39; 10:28; 17:12; and 18:9 $\dot{\alpha} \pi \hat{\prime} \lambda \lambda v \mu \mathrm{u}$ refers to the disciples or believers (which are synonyms) and in 6:12.27 to the bread of life. In 10:10 it refers to the thief who comes only to steal, slaugh-

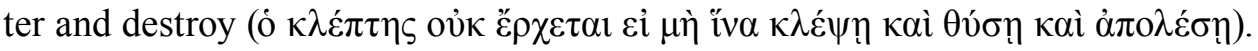
The subject o $\kappa \lambda \dot{\varepsilon} \pi \tau \eta \varsigma$ is employed by John only in the metaphor about the Good Shepherd (10:1.8.10) and to describe Judas in 12:6 (!). In the prophecy of Caiaphas it refers to the perishing of the nation (11:50). In 12:25 $\alpha$ jó $\lambda \lambda \nu \mu 1$ appears in a traditional logion, well attested in the Synoptic tradition, ó $\varphi \imath \lambda \tilde{\omega} v \tau \eta \dot{\nu} v \psi v \chi \eta े v \alpha v ่ \tau o \tilde{v}$

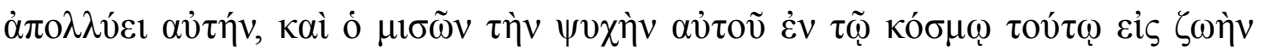

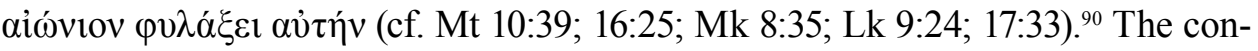
trast with $\varphi v \lambda \alpha \dot{\sigma} \sigma \sigma \omega$ favours the meaning "destroy" here. The same contrast occurs in 17:12. ${ }^{11}$ Let us note that in the first group of occurrences (connected with the idea of discipleship) $\dot{\alpha} \pi$ ó $\lambda \lambda v \mu 1$ appears always with a negation $\mu$ ' or, as in 17:12 and 18:9, with the indefinite pronoun ovjocís which has the same semantic function, i.e., negation. Indeed, the affinity between 17:12 and 18:9 is underscored.

The verb $\delta i \delta \omega \mu l$. The motif of giving by the Father is quite frequent in John. The verb $\delta i \delta \omega \mu$ pertains to the divine activity of God, the Father, the sender etc. 32 times (out of 75 occurrences of $\delta i \delta \omega \mu$ in the Fourth Gospel).

aorist $\grave{\varepsilon} \varphi v ́ \lambda \alpha \xi \alpha$, "I protected" (not "I have protected"), implies action regarded simply as past. Cf. E.A. Abbott, Johannine Grammar (London: Adam \& Charles Black 1906) § 2584. E.D. Freed (Old Testament Quotations, 97) argues: "It is interesting to note here that Jn much prefers $\tau \eta \rho \varepsilon ́ \omega$ (17 times) to $\varphi v \lambda \alpha ́ \sigma \sigma \omega$ (only in 12:25, 47 and 17:12). But $\varphi v \lambda \alpha ́ \sigma \sigma \omega$ could be only a stylistic variation for $\tau \eta \rho \varepsilon ́ \omega$ in 17:12 since the latter occurs earlier in the vs."

90 Despite the fact that all four Gospel use the verb $\dot{\alpha} \pi{ }^{\prime} \lambda \lambda \nu \mu \mathrm{t}$ to express the first part of the logion, they

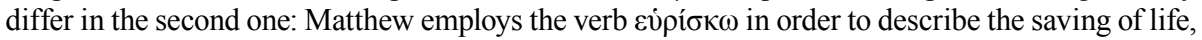
Mark uses $\sigma \omega \dot{\zeta} \omega \omega$ and Luke in the first occurrence $\sigma \omega \dot{\zeta} \omega$ and in the second $\zeta \omega o \gamma o v \varepsilon \dot{\omega} \omega$. Moreover, at variance with the Synoptics John adds the idea of eternal life. Cf. W. Rebell, "«Sein Leben verlieren» (Mark 8,35 parr.) als Strukturmoment vor- und nachösterlichen Glaubens”, NTS 35 (1989) 202-218; J. Caba, "Dalla parenesi lucana alla cristologia giovannea. Studio comparato di Lc 9,23-24 e Gv 12,25-26", Luca-Atti. Studi in onore di P. Emilio Rasco nel suo $70^{\circ}$ compleanno (ed. G. Marconi - G. O’Collins) (Assisi: Cittadella 1991) 72-104; M. Morgen, “«Perdre sa vie». In 12,25: un dit traditionnel?", RSR 69/1 (1995) 29-46; F. Neirynck, "Saving/Losing One's Life. Luke 17,33 (Q?) and Mark 8,35", Evangelica III. 1992-2000. Collected Essays (BEThL 150; Leuven: Leuven University Press 2001) 480-503; P. Pokorny, "Lukas 17,33parr. - Die Geschichte Jesu und ein (damals) bekanntes Sprichwort", For the Children, Perfect Instruction. Studies in Honor of Hans-Martin Schenke on the Occasion of the Berliner Arbeitskreis für koptisch-gnostische Schriften's Thirtieth Year (ed. H.-G. Bethge - S. Emmel - K.L. King) (NHMS 54; Leiden: Brill 2002) 387-398.

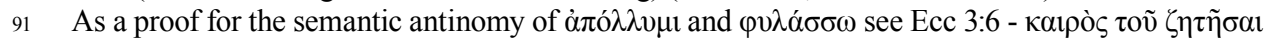

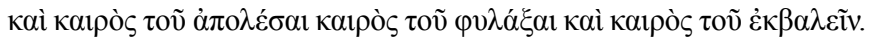




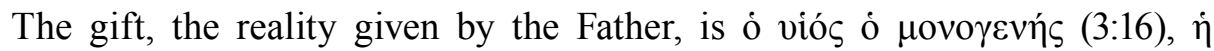

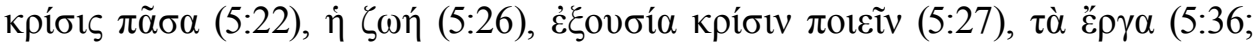

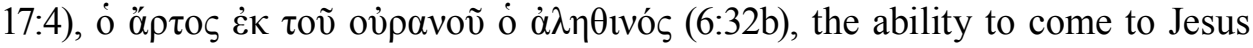

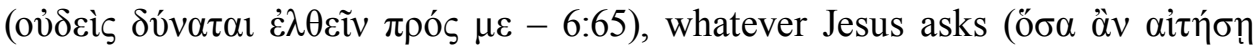

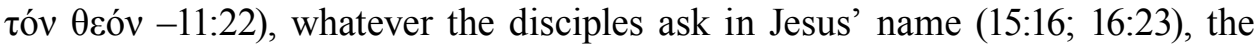

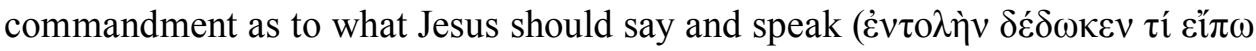

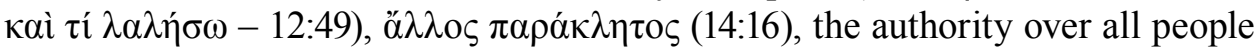

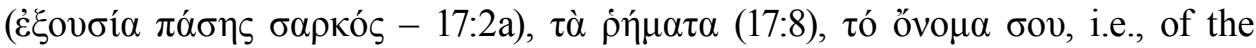

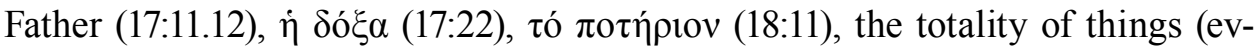
erything or anything $-3: 27.35 ; 13: 3 ; 17: 7)$ and finally, the largest set, a totality of

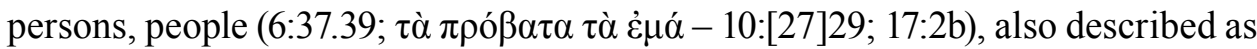
Jesus' disciples (17:6bis-à $v \theta \rho \omega ́ \pi 01.9 .11 .24 ; 18: 9)$.

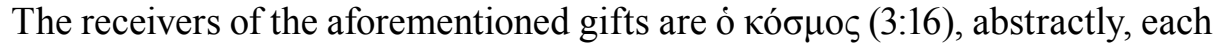
human being - óv $\theta \rho \omega \pi \mathrm{o} \varsigma$ (3:27), the people from the crowd, Jesus' interlocutors in $6: 32 b$, oi $\mu \alpha \theta \eta \tau \alpha i$ (6:65) also during the farewell speech $(14: 16 ; 15: 16 ; 16: 23)$ and, finally, in the majority of cases, Jesus, described by the noun ó vió $\varsigma(3: 35$; $5: 22.26)$ or by the simple personal pronoun $(5: 27.36 ; 6: 39 ; 10: 29 ; 11: 22 ; 12: 49$; 13:3; 17:2bis.4.6bis.7.8.9.11.12.22; 18:9.11).

The divine giver is described as ó $\theta \varepsilon$ ós, never in Jesus' mouth (3:16;

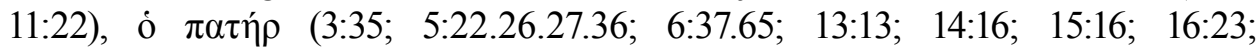

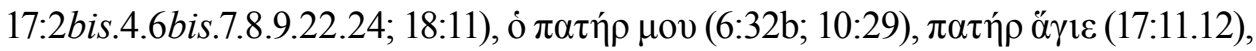

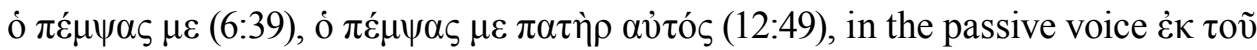

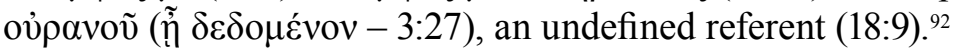

As regards the idea of being given his name by the Father, it is only found in Jn 17:11.12. ${ }^{93}$ Even in LXX there is no connection between the noun ovo $\mu \alpha$, referring to God, and the verb $\delta i \delta \omega \mu$ with a divine subject. The closest idea would be the motif of giving glory ( $\delta$ ó $\xi \alpha$ or $\mu \varepsilon \gamma \alpha \lambda \omega \sigma u ́ v \eta$ ) "to God's name" (even by God

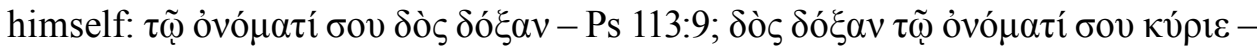
Odes 7:43; Dan 3:43; with human subjects - Paraleipomena [1Chronicles] 16:29; Ps 65:2; Sir 39:15; Mal 2:2).

The table below lists all instances of the aforementioned verbs in the Fourth Gospel.

92 From the perspective of the whole NT, W. Popkes (" $\delta i \delta \omega \mu$ ", $E D N T, \mathrm{I}, 321)$ observes that "God is mentioned directly as the giver in 104 passages, of which 42 are in John and 1-3 John while 19 occur in Acts, in contrast to the 28 occurrences in the Pauline corpus (of which 11 are in 1-2 Corinthians) and only 7 in the Synoptics (not in Mark). God's act of giving is nevertheless indirectly stated in

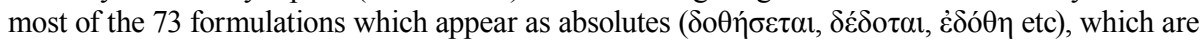
distributed in a different way: 22 in Revelation, 11 in Matthew, 8 in Luke, 5 each in Mark, 1 Corinthians, and Ephesians, and hardly any in John, Acts, and the later Epistles."

93 B.F. Westcott (John, 243) observes on v. 11: "The phrase is very remarkable, and has no exact parallel except in v. 12". 


\begin{tabular}{|c|c|c|c|}
\hline \multirow[t]{2}{*}{ 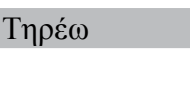 } & $\varphi v \lambda \alpha ́ \sigma \sigma \omega$ & $\dot{\alpha} \pi{ }^{\prime} \lambda \lambda v \mu \imath$ & $\delta i \delta \omega \mu \imath$ \\
\hline & & & $1: 12.17 .22$ \\
\hline \multicolumn{4}{|l|}{ 2:10 } \\
\hline & & 3:16 & 3:16.27.34.35 \\
\hline & & & 4:5.7.10bis. 12.14 bis. 15 \\
\hline & & & $5: 22.26 .27 .36$ \\
\hline & & $6: 12.27 .39$ & $\begin{array}{l}\text { 6:27.31.32bis.33.34.37. } \\
\text { 39.51.52.65 }\end{array}$ \\
\hline & & & $7: 19.22$ \\
\hline \multicolumn{4}{|l|}{$8: 51.52 .55$} \\
\hline \multirow[t]{3}{*}{$9: 16$} & & & $9: 24$ \\
\hline & & $10: 10.28$ & $10: 28.29$ \\
\hline & & $11: 50$ & $11: 22.57$ \\
\hline \multirow[t]{2}{*}{$12: 7$} & $12: 25.47$ & $12: 25$ & $12: 5.49$ \\
\hline & & & 13:3.15.26bis. 29.34 \\
\hline $14: 15.21 .23 .24$ & & & 14:16.27thrice \\
\hline \multirow[t]{2}{*}{ 15:10bis.20bis } & & & $15: 16$ \\
\hline & & & $16: 23$ \\
\hline \multirow[t]{4}{*}{ 17:6.11.12.15 } & $17: 12$ & $17: 12$ & $\begin{array}{l}\text { 17:2thrice.4.6bis.7.8bis } \\
\text { 9.11.12.14.22bis.24bis }\end{array}$ \\
\hline & & 18:9 & 18:9.11.22 \\
\hline & & & 19:3.9.11 \\
\hline & & & $21: 13$ \\
\hline
\end{tabular}

As it turns out, there are seven passages in which at least two of the lexemes in question appear together. Among those we can exclude 3:6; 6:27 and 12:25, since each conveys a different idea (first, giving the Son and having faith in him to preserve his own life; second, the Son of Man, a giver of the bread which does not perish; third, a lover of his life destroys it and the one who hates it guards it). The four remaining parallel texts are united by the same idea of none of the disciples perishing. They constitute a logion of Jesus on his disciples "not perishing".

\subsubsection{Johannine Logion on Jesus' Disciples "Not Perishing"}

The four Johannine texts dealing with the idea of Jesus' disciples not perishing share the same lexical features. Let us examine them side by side:

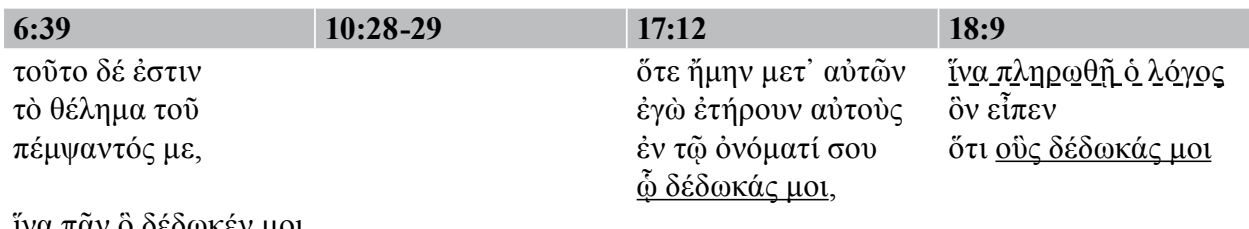




\begin{tabular}{|c|c|c|c|}
\hline & 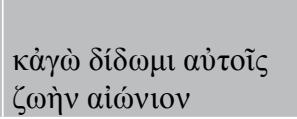 & 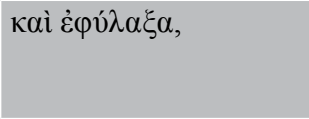 & \\
\hline 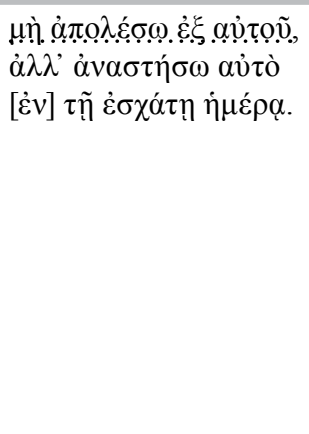 & 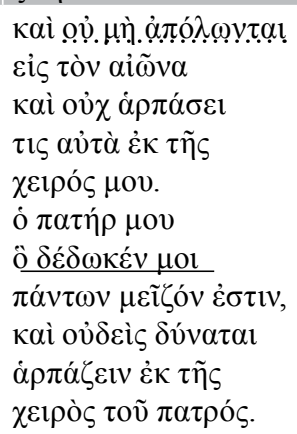 & 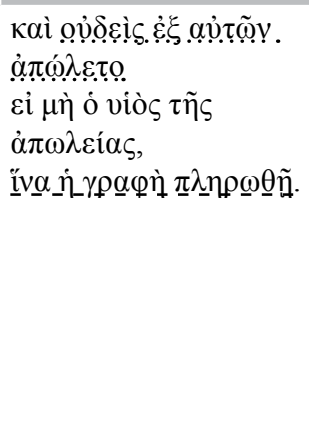 & 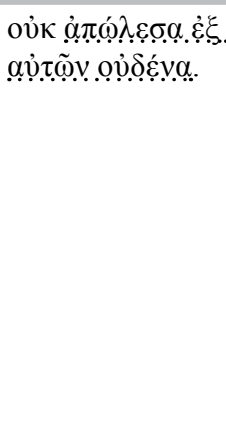 \\
\hline
\end{tabular}

The affinity of $6: 39 ; 10: 28-29$ and 18:9 is self-evident on the level of vocabulary. The contention is that one is dealing here with a traditional Jesus-logion about his disciples not perishing. The identification of it is facilitated by the presence of an auxiliary motif, namely the idea of the disciples being given by the Father.

In the case of 6:39 and 10:28-29 there is a sort of foretelling or promise referring to the future. By contrast, in 17:12 and 18:9 the temporal perspective

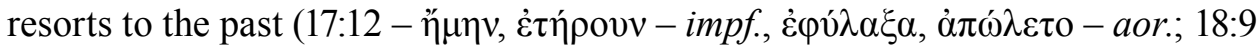
$-\dot{\alpha} \pi \dot{\omega} \lambda \varepsilon \sigma \alpha-a o r$.). The fact that 17:12 appears to be told from the same temporal perspective as 18:9 is surprising to the extent that one understands the fulfilment of the announcement of the disciples not perishing in a very literal (physical) sense. ${ }^{94}$ Verse 18:9 is not an uninformed redactional note referring to the protection of the disciples from the troops, but, as C.H. Dodd points out, "to their protection from spiritual perils that menace their eternal salvation"..$^{95}$ The whole idea of not perishing then refers not to the physical rescue of the group of the disciples in the garden, but to their salvation, which becomes clear if we look at all occurrences of the logion. The telling strong point of this interpretation is the

94 C.K. Barrett (John, 521) explains: "This verse [18:9] has been taken to be a redactional gloss, exhibiting a crassly materialist and prosaic misunderstanding of 17:12."

95 C.H. Dodd, The Interpretation of the Fourth Gospel (Cambridge: Cambridge University Press 1953) 432. Verse 18:9 is regarded as a redactional interpolation by A. Schweizer (1841), J.H. Scholten (1864), H.H. Went (1896, 1900, 1910), F.W. Lewis (1909-11), J.M. Thompson (1917), H.J. Flowers (1921), B.W. Bacon (1900, 1903, 1933), J. Wellhausen (1907), E. Schwartz (1907-08), W. Bousset (1909), F. Spitta (1910), A. Meyer (1910), G.H.C. MacGregor (1928), E. Hirsch (1931), R. Bultmann (1941), R.E. Brown (1970), S. Schulz (1972), H.M. Teeple (1974), S. Temple (1975), W. Langbrandtner (1977), J. Becker (1981), M. Myllykoski (1991). For the exact references see G. Van Belle, „L'accomplissement de la parole de Jésus. La parenthèse de Jn 18,9”, The Scriptures in the Gospels (ed. C.M. Tuckett) (BEThL 131; Leuven: Leuven University Press 1997) 617-618. Gilbert Van Belle („L'accomplissement”, 626-627) observes, "le style et le vocabulaire de la parenthèse de 18,9 sont johanniques et son contenu s'accorde avec la representation du Christ dans la passion johannique. En plus, la parenthèse cadre bien dans le context." 


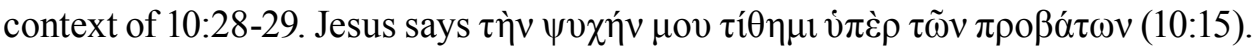
It expresses the full, rich content embodied in the words of 17:12 and 18:9. In the garden, Jesus went to meet his enemies just as "the Shepherd went to meet the wolf to save his flock". ${ }^{96}$

I would suggest that the idea of not perishing could be understood as an illustration both of eternal salvation and of keeping their faith in Jesus. It is clear by the use of the verb $\eta \mu \eta v$ in 17:12 that as long as Jesus was with the disciples they were preserved in this faith, were not lost in unbelief and did not perish. Again, because of the fact that Jesus $i$ s with them in 18:8-9 they are kept and preserved. There is no sign of the disciples' failure. They are even courageous in their actions, if one takes into consideration Peter's behaviour in 18:10-11, as well as his following Jesus in 18:15 together with "the other disciple". Even so, once Peter was bereft of Jesus' presence, he lost his courage and failed to keep his faith (18:17.25-27).

\subsubsection{Disciples or Father's Names? A Controversial Direct Object of $\delta i \delta \omega \mu \mathrm{t}$ in 17:12}

The direct object of the verb $\delta i \delta \omega \mu$ differs substantially in 17:12 from the other three texts. In 6:39; 10:28-29 and 18:9 the Father gives the disciples to the Son, while in 17:12 the dative neuter $\tilde{\omega}$ no doubt refers to the Father's name and not to the disciples. There is yet another lesson, the plural oú $\varsigma$ which refers to the disciples (cf. 18:9). If we deal here, as we believe, with a traditional Jesus-logion, such a variant should not be surprising.

One could attempt a conjectural reconstruction of the subsequent textual changes of the verse 17:12 in order to explain the variety of the preserved lessons. First, there is no doubt among the ancient witnesses regarding the presence of the expression $\dot{\varepsilon} v \tau \tilde{\varphi}$ óvó $\mu \alpha \tau i$ oov in 17:12 as well as in 17:11. Secondly, the most unusual variant (difficilior lectio potior) seems to be the neuter $\tilde{\tilde{\omega}} \delta \varepsilon \delta \delta \omega \kappa a ́ \varsigma$ $\mu o t$ in 17:11, i.e., referring to the Father's name, ${ }^{97}$ and it should be preserved as an original reading, because no one could conceive such an unusual lesson. Thirdly, the simplest syntactical structure of 17:12 seems to prefer the following, logically

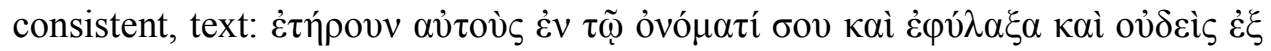
$\alpha \dot{\tau} \tau \tilde{\omega} v \dot{\alpha} \pi \hat{\prime} \lambda \varepsilon \tau$. Indeed, this version of the text is attested by $\mathrm{P}^{66^{*}} \boldsymbol{\aleph} *$ and Synaitic

96 Dodd, Interpretation, 433.

97 The association between the Father's name and his giving appears in the Fourth Gospel only once,

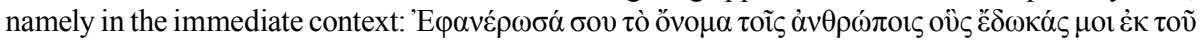
кó

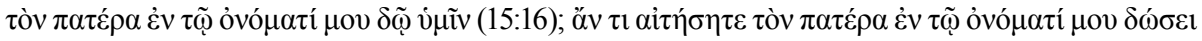
vนĩv (16:23). 
Syriac. ${ }^{98}$ Subsequently, two other texts had an impact on this version of the text:

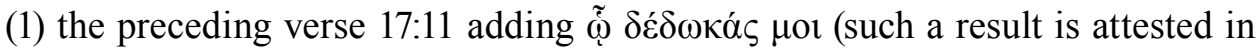
17:12 by B L 33 Sahidic, Proto-Bohairic, Bohairic, Subakhmimic, Armenian, Georgian $\left.^{1}\right)^{99}$ and (2) the Jesus-logion from 18:9 (cf. 6:39; 10:29) and other passages that contain the idea of the disciples being given by the Father (e.g., verbatim 17:6; cf. also 17:2.6.9.11.24) adding oú $\delta \varepsilon \delta \delta \kappa \alpha \varsigma \mu \mathrm{ol}$ (attested in 17:12 by A C $\mathrm{C}^{\mathrm{c}}$ D C Q Y M N U f $f^{12}$ Byzantine Koine, VL and Vg [quos dedisti mihi], Syriac [Peshitta, Harklensis], Georgian ${ }^{2}$ ). Of course, the above-mentioned reconstruction is totally hypothetical, even if it can account well for the present range of variants preserved in the manuscripts. ${ }^{100}$

In order to simplify the aforementioned proposal, and to make it even more reasonable, I would argue for the originality of a reading with $\tilde{\omega} \delta \varepsilon \dot{\varepsilon} \delta \omega \alpha \dot{\varsigma} \mu \mathrm{ot}$ in

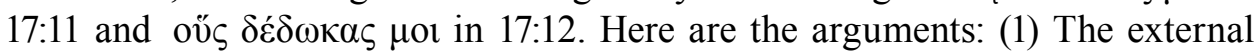
support for oű $\varsigma$ in verse 12 is much stronger than in verse 11. (2) Moreover, it is very easy to account for the reading $\tilde{\hat{\varphi}}$ in verse 12 as a conformation to v. $11(\tilde{\hat{\omega}}$

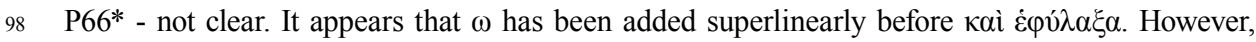
only part of the letter is visible so we cannot determine with absolute certainty if it really refers to $\tilde{\omega} \delta \dot{\delta} \delta \omega \kappa \alpha ́ \varsigma \mu \mathrm{ot}$. Cf. The Text of the Earliest New Testament Greek Manuscripts. A Corrected, Enlarged Edition of the Complete Text of the Earliest New Testament Manuscripts (ed. P.W. Comfort - D.P. Barrett) (Wheaton: Tyndale House Publishers 2001) 123. Synaitic Syriac omits also kaì

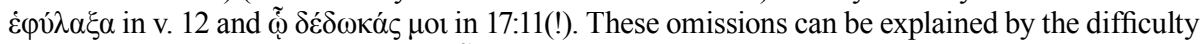

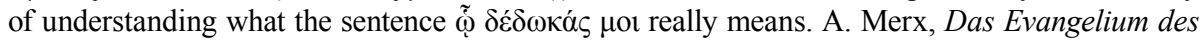
Johannes nach der Syrischen im Sinaikloster gefundenen Palimsesthandschrift (Berlin: Reimer 1911) 418-419 as well as M.-É. Boismard - A. Lamouille, L'Évangile de Jean (Synopse des quatre Évangiles en français 3; Paris: Cerf 1987) 392, all opt for the originality of the short text attested by Synaitic Syriac.

$99 \quad$ In a few witnesses (i.e. $\left.C^{*} \mathrm{~W} 579\right)$ there is $\omega \varepsilon \delta \omega \kappa \alpha \varsigma \mu$ ot.

100 As it turns out, our proposal is in total harmony with the argumentation of M.-É. Boismard and A. Lamouille (Jean, 392): "Nous préférons toutefois la leçon courte de P66 et S ; les deux autres leçons s'expliquent par harmonisation avec le v. 11, d'où l'addition des mots « que (hô) tu m'as donné » ou « ceux que (hous) tu m'as donnés. » Si la leçon du texte Alexandrin [⿳َ̃ ] était primitive, il serait beaucoup plus difficile d'expliquer la naissance du texte court." There is also a third variant, ô $\delta \varepsilon ́ \delta \omega \kappa \alpha ́ \varsigma ~ \mu o t$, found only inא c (according to Tischendorf also in Coptic and Armenian). [D* U X 157] The ambiguous Greek neuter ő could be instantly corrected either to another neuter $\tilde{\omega}$ (referring to the Father's name) or to oü (referring to the disciples and perfectly fitting the Johannine context - the neuter also denotes the disciples in 6:37.39; 10:29; 17:2.24). Moreover, this lesson can be easily accounted for thanks to the reference to the alleged Aramaic original, namely the difficulty in translation of the ambiguous relativer . In C.F Burney's opinion the genderless 7 was rendered by neuter ő, "which easily lent itself to correction into $\tilde{\hat{\omega}}$ " but "oû the meaning originally intended." C.F. Burney, The Aramaic Origin of the Fourth Gospel (Oxford: Clarendon 1922) 103. J. Huby, "Un double problème de critique textuelle et d'interprétation. Saint

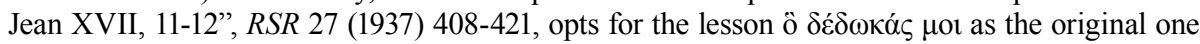

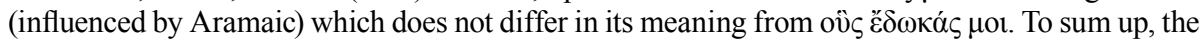
existence of the Aramaic Vorlage is purely hypothetical, nevertheless it well accounts for the presence of three different readings ( $\tilde{\omega}$, ő, oús). E. Martín Nieto, "El nombre de Dios en S. Jh., 17, 11-12",

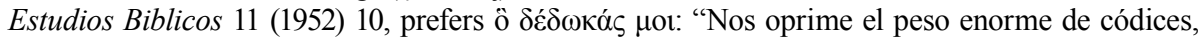
versiones, ediciones críticas y comentarios." 
is better attested in v. 11 than in v. 12). (3) In our contention, the weight of the witnesses (external criticism) favours equally either reading $(\tilde{\hat{\omega}}$, oũ $\varsigma)$ in v. 12 , yet there is a slight preference for the lesson oüc. (4) The reading most in accord with John's style seems to be oúc. First, because it reflects John's frequent thought about the Father who gives the disciples (present also in the immediate context - 17:6.24; cf. 17:2.9). Secondly, it is John's habit to repeat entire expressions, phrases or sentences side-by-side with only slight changes, in order to introduce a new thought or to push the narration ahead. In this case $\tilde{\varphi} \delta \varepsilon \dot{\varepsilon} \delta \kappa \alpha ́ \varsigma \mu \mathrm{ot} \mathrm{in} \mathrm{v.} 11$ is changed to oú $\delta \varepsilon \delta \delta \omega \kappa \alpha \varsigma \mu \mathrm{ol}$ in v. 12. The verbatim repetition of the entire

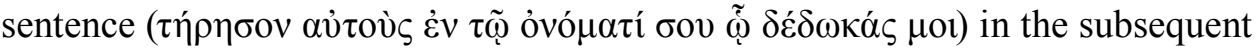

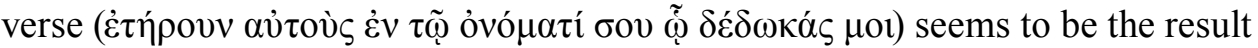
of the copyist's tendency toward uniformity (or a simple mistake) rather than a real reflection of the Johannine style.

To sum up, whatever the case might be, ${ }^{101} \mathrm{I}$ would argue for the utility of the textual criticism in establishing the link between 17:12 and the other three texts containing the same Jesus-logion, namely $6: 39 ; 10: 28-29 ; 18: 9$. However, even the lesson referring to the Father's name does not rule out the connection with 18:9. R.E. Brown and W.E. Sproston, for instance, argue that the usage of $\tau$ o óvo $\mu \alpha$ in 17:12 in all probability anticipates what is to happen in 18:5-6, where "the protective power of God's name is seen in action." ${ }^{102}$

\subsubsection{Is Jesus' Word the Referent of $\dot{\eta}$ Y $\rho \propto \varphi \eta ́$ in John 17:12?}

According to W.E. Sproston, for John there is no semantic difference between

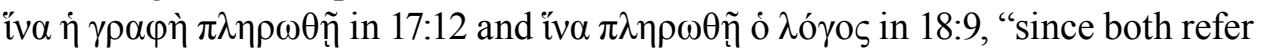
to the same Jesus-Logion on the unassailability of those given him by the Father and in both cases the Logion is quoted". ${ }^{103}$ That being so, it means that John used the term $\dot{\eta} \gamma \rho \alpha \varphi \eta$, normally employed by him to denote the $\mathrm{OT}^{104}$, for Jesus' own

101 See, for instance, B. Lindars' (John, 525) opinion: "It is clear that the harder reading which [name] thou hast given me is to be retained, even though we may suspect that the phrase was originally only found in one or other of the two verses rather than in both."

102 Brown, John, 764; Sproston, “«The Scripture» in John 17:12”, 32.

103 Sproston, "«The Scripture» in John 17:12", 32. Sanders - Mastin, John, 373: "That none of them is lost (cf. vi. 39; x. 28f.) came to have the status of a prophecy (xviii. 9) before the FG received its final form; Jesus' words, or the words of a Christian prophet spoken in his name, could have the same validity as the Old Testament (cf. ii. 22; xviii. 32). This is natural in view of the fact that Jesus' words are the Father's words (xiv. 24). Although this verse has a wider significance, the scene in the Garden exemplifies what is intended."

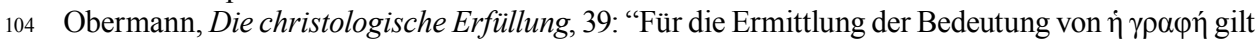
es, den jeweiligen Kontext mit in den Blick zu nehmen, wobei sich insgesamt drei unterschiedliche Bezugsgrößen für $\dot{\eta} \gamma \rho \alpha \varphi \eta ́$ ausmachen lassen. Und zwar kann der Singular $\dot{\eta} \gamma \rho \alpha \varphi \eta ́$ (erstens) die Bedeutung eines einzelnen Schriftwortes haben wie auch (zweitens) für die Schrift insgesamt 
word. Was John accustomed to treating the Jesus-Logia in the same way that he treated texts with having the authority of the Hebrew Bible, called "Scriptures" ( $\alpha i$ i $\rho \alpha \varphi \alpha i)$ ? The telling signs of John's tendency to place the words of Jesus on a level with the Scripture are found in the Gospel itself: ö $\tau \varepsilon$ oũv $\eta \gamma \varepsilon \dot{\varepsilon} \rho \eta$

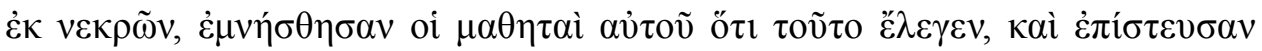

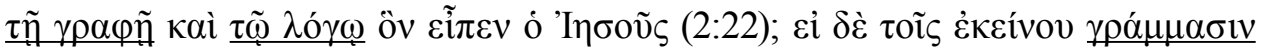

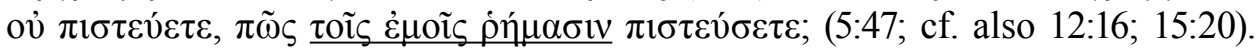
Moreover, uniquely in John 18:9.32 the construction iv $\alpha \alpha \lambda \eta \rho \omega \theta \tilde{\eta}$ is used for the fulfilment of words of Jesus, while elsewhere in the New Testament and in the Fourth Gospel itself $(12: 38 ; 13: 18 ; 15: 25 ; 19: 24 ; 19: 36)$ it refers to the fulfilment of OT passages. ${ }^{105}$ W.E. Sproston avoids the conclusion that John made a conscious move to call a Jesus-Logia "Scripture". ${ }^{106}$ In her opinion, a looser rendering of $\dot{\eta} \gamma \rho \alpha \varphi \eta$ in 17:12, as tradition or writing, may be more suitable. ${ }^{107}$ From a historical perspective, given the paradigm of the Gospel as arriving at its final shape by gradual growth, this contention seems plausible. Of course, at this point one could assume the existence of the collection of Jesus-Logia ${ }^{108}$ or similar texts ${ }^{109}$ which were read and commented upon in the assembly, accompanied by the Paraclete (14:26; 16:12-13), and eventually incorporated into the final body of the gospel..$^{110}$

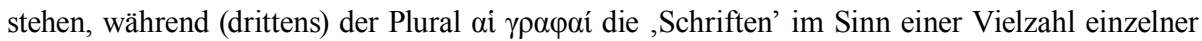
Schriften meint."

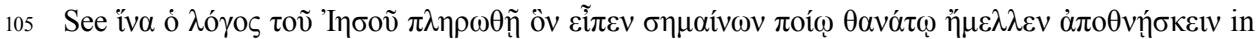

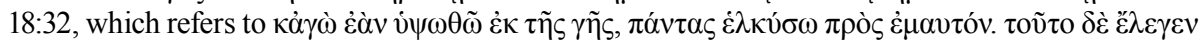

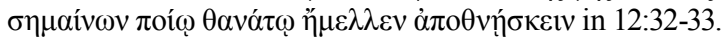

106 See the critique of her views by D.A. Carson, The Gospel according to John (PNTC; Grand Rapids, MI: Eerdmans - Leicester, U.K.: Apollos 1991) 565, note 14, "That the Evangelist can cite Jesus' words and assign them the highest authority cannot be doubted; that he could place on Jesus' lips a citation of Jesus' own words and refer to them as Scripture is wholly implausible."

107 Sproston, “《The Scripture» in John 17:12", 32.

108 For its existence as the basis of John's midrashic style of composition see M. Wilcox, "The Composition of John 13:21-30", Neotestamentica et semitica. Studies in Honour of Matthew Black (ed. E.E. Earle - M. Wilcox - M. Black) (Edinburg: T \& T Clark 1969) 143-156; B. Lindars, "Traditions behind the Fourth Gospel', L'Évangile de Jean. Sources, rédaction, théologie (BEThL 44; Gembloux: Duculot - Leuven: Leuven University Press 1987) 107-124; P. Borgen, "The Use of Tradition in John 12:44-50", NTS 26 (1979-1980) 18-35.

109 For instance, it could be something parallel to the so-called testimonia - the hypothetical proposition that the earliest Christians collected, edited, and gave authoritative interpretations to a selected group of scriptural quotations which served as proof-texts for basic Christian beliefs. For more on this subject see M.C. Albl, "And Scripture Cannot Be Broken". The Form and Function of the Early Christian Testimonia Collections (NT.S 96; Leiden: Brill 1999).

110 There is also a view that chapters $15-17$ are a later addition to the main body of the gospel. I. Hammer, defending the historicity of these words, argues that they were delivered by Jesus between the resurrection and the ascension. I. Hammer, "Eine klare Stellung zu Joh. 14.13b", Bibel und Kirche $14 / 2$ (1959) 33-40. 
The conclusion that $\dot{\eta} \gamma \rho \alpha \varphi \eta$ in 17:12 should be understood as Jesus' word was reached by Francis J. Moloney. ${ }^{111}$ In the Gospel itself one can detect indications allowing such a conclusion: first, a clear awareness of the fulfillment ( $\pi \lambda \eta \rho$ ó $\omega$, $\tau \varepsilon \lambda \varepsilon i o ́ \omega)$ and perfection ( $\tau \dot{\lambda} \lambda \circ \varsigma$ ) of the Scriptures in Jesus; secondly, the fact that

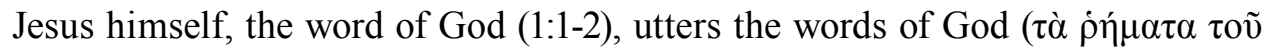
$\theta \varepsilon \circ \tilde{v} \lambda \alpha \lambda \varepsilon \tilde{\imath}-3: 34$; cf. 14:24) and does what God does (5:19), because he is one with God (19:30.38; 14:1.11); and third, the aforementioned placing of the word ( $\lambda$ ó $\left.{ }^{\circ} \varsigma\right)$ of Jesus on the same level as the word ( $\gamma \rho \alpha \varphi \eta$ ) of the Scripture (2:22; cf. 5:47) which means that the word of Jesus is the Scripture.

It is incontrovertible that in the understanding of the Fourth Evangelist, the

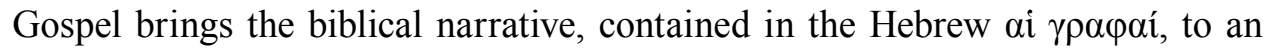
end. ${ }^{112}$ First, in the initial part of the evangelical story, the narrative tradition of the $\gamma \rho \alpha \varphi \eta$ of the OT continues on into the Gospel of John. The references to the OT serve as a background to John's claims about Jesus. They provide the correct explanation of who Jesus is. Secondly, in the next section of the Gospel

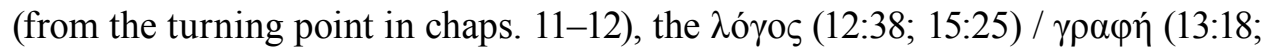
19:24.28.36) of the OT comes to its completion. This shift is easily seen by the use of the fulfillment formula (iv $\alpha \pi \lambda \eta \rho \omega \theta \tilde{\eta}$ ). ${ }^{113}$ The climax of the process of fulfilling the Scriptures is reached in 19:28 where the customary verb $\pi \lambda \eta \rho o ́ \omega$ is replaced by $\tau \varepsilon \lambda \varepsilon$ ió $\omega$. The death of Jesus fulfils the promises of the OT and also brings them to their $\tau \varepsilon \dot{\lambda}{ }_{0} \varsigma_{.}{ }^{14}$ The consciousness that Jesus is the final word of God, the Word itself, which closes the biblical narrative and the Scriptures, prompted the author of the Fourth Gospel not only to understand Jesus' words as having the same authority as the Scriptures but also to understand his own writing as Scripture itself. As F.J. Moloney puts it, "there may be [...] indications within the Johannine story of Jesus that indicate an author who laid explicit claim to be writing $\gamma \rho \alpha \varphi \eta^{\prime \prime}{ }^{115}$ The telling examples of this are verses 2:22, 20:9 and 17:12.

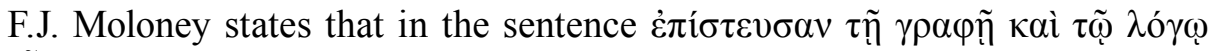

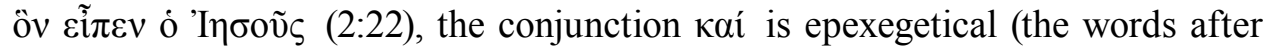

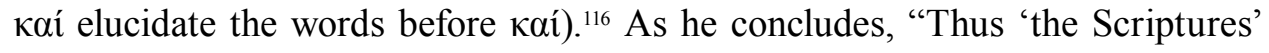

111 Moloney, "The Gospel of John as Scripture", 454-468; Cf. also Moloney, "What Came First", 12-20.

112 It is thoroughly proved by A. Obermann, Die christologische Erfüllung, 215-217.325-330.350-364.

113 C.A. Evans, "On the Quotation Formulas in the Fourth Gospel", BZ 26 (1982) 79-83.

114 See also F.J. Moloney, "The Gospel of John: The "End" of Scripture", Interpretation 64 (2009) 356-366.

115 Moloney, "The Gospel of John as Scripture”, 456.

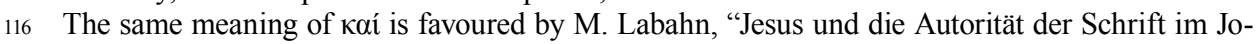
hannesevangelium. Überlegungen zu einem spannungsreichen Verhältnis", Israel und seine Heilstraditionen im Johannesevangelium. Festgabe für Johannes Beutler SJ zum 70. Geburtstag (ed. M. Labahn - K. Scholtissek - A. Strotmann) (Paderborn: Schöningh 2004) 187: "Schrift und Wort sind unterschiedslos neben einander gestellt als gleichwertige Autoritäten, die im Gefälle johanneischer Hermeneutik zum Glauben führen". 
and 'the word that Jesus had spoken' are, for this author, one and the same thing. The word of Jesus, who is the Word of God become flesh $(1: 1-2,14)$, is Scripture, 'remembered' by the disciples after Jesus has been raised from the dead (2:22)." "17 As for the second example, there appears to be a contradiction between an affirmation of the faith of the Beloved Disciple in 20:8 and the remark about the disci-

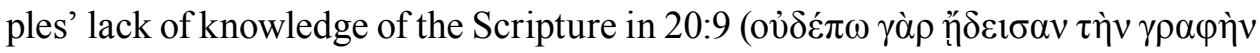

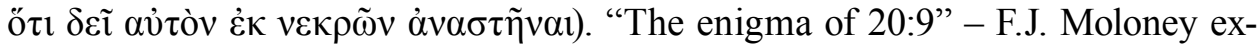
plains - "is resolved if we recognize that, for its author, the Johannine narrative is itself "Scripture", but the characters in the story are not able to be readers of the story. Peter and the Beloved Disciple are in a 'not yet' [ov่ $\delta \varepsilon \dot{\pi} \omega]$ situation as far as the $\gamma \rho \alpha \varphi \eta$ of the Johannine narrative is concerned. A later generation may not be able to penetrate the tomb and see the cloths, and thus they come to faith without seeing Jesus. For the author of the Gospel of John, however, they are in a more privileged situation. They have the Scripture of the Gospel of John, and thus they can match the faith experience of the Beloved Disciple." ${ }^{118}$ Finally, coming back to $17: 12$, F.J. Moloney states that "despite scholarly debate over a possible 'Scripture' that might be behind the fulfillment formula in 17:12 the answer is not to be found in the Scripture of the OT. In 18:9 the Scripture of 17:12 is clarified as the word Jesus had spoken. The close juxtaposition of 17:12 and 18:9 enables the author to draw a parallel between $\dot{\eta} \gamma \rho \alpha \varphi \eta ́$ and ó $\lambda$ ó $\gamma \circ \varsigma .{ }^{119}$

Both W.E. Sproston and F.J. Moloney conclude that $\eta$ $\gamma \rho \alpha \varphi \eta$ in Jn 17:12 refers to Jesus' words. However, they reach this conclusion by different paths. Sproston's perspective is historical-critical; she looks for the early strata of the gospel story (Jesus-Logia). Moloney's approach is purely synchronic, starting from the hermeneutical premise that the (final) text of the Gospel is Scripture itself, and the author was writing it with the consciousness of writing Scripture. Therefore, the author felt free in making interconnections between Jesus' words and the notion of Scripture $(2: 22 ; 17: 12)$, as well as in moving beyond the temporal frame of the narrative itself (20:9).

No doubt, the contention that the author of the Gospel of John thought that he was writing sacred Scripture is rather surprising. We are accustomed to thinking that the semantics of $\gamma \rho \alpha \varphi \eta$ in John is always connected with the OT. Even F.J. Moloney himself admits that, in his earlier teaching career, under the influence of form and redaction criticism, he may have ridiculed any such suggestion. However, looking at the Fourth Gospel from the viewpoint of a reader-oriented and holistic reading that is to say, employing all the achievements of modern narrative criticism - one has to admit that John's Gospel was written to persuade its hearers and readers that

117 Moloney, "The Gospel of John as Scripture", 464.

118 Moloney, "The Gospel of John as Scripture", 466. On this understanding of $\gamma \rho \alpha \varphi \eta$ in 20:9, see

Moloney, "«For as yet they did not know the Scripture» (John 20,9)", 97-111.

119 Moloney, "The Gospel of John as Scripture", 461. 
biblical history reached its perfection in the Johannine story of Jesus. In summary, John's Gospel itself is the ultimate Scripture which fulfils and closes the Scriptures.

\section{Conclusion}

Our inquiry into the possible referent of $\dot{\eta} \gamma \rho \alpha \varphi \eta$ in John 17:12 has revealed the very complexity of the issue. We have seen that the fulfillment of the Scripture here can refer to either the tragic fall of Judas or the preservation in faith of Jesus' disciples. But perhaps this "either/or" choice is not the only one. It might also be true that the author of the Fourth Gospel was convinced that both Judas' lot and the fate of Jesus' other disciples were envisioned in the Scripture. As demonstrated above, many scriptural passages might be invoked to argue for either connection. The tragic fate of the impious is a leitmotif of the Scripture, and the same can be said about the glorious fate of the pious believer. I would concur with J. Ramsey Michaels's view that no one biblical text is in view, but a general tenor of Scripture is evoked. ${ }^{120}$ The use of $\gamma \rho \alpha \varphi \eta$ in John 17:12 would then be analogous to the use of $\gamma \rho \alpha \varphi \eta$ in John 19:28. If one wishes, however, to pinpoint one precise scriptural passage, U.C. von Wahlde's proposal of referring to Prov 24:22 seems very attractive. It alludes explicitly to the disciples, who are guarded from perdition, but it also alludes implicitly to Judas, as the one who actually perished. The hypothesis of seeing Jesus' own words as the referent of $\dot{\eta} \gamma \rho \alpha \varphi \dot{\eta}$, while innovative and appealing, has also its weak points. Among these, the most important is the fact that the Johannine concept of fulfillment of Scripture is always referred to the Old Testament. Nevertheless, the functional correspondence

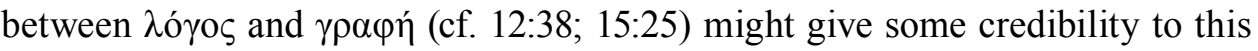
hypothesis. Taking into account the Johannine predilection for double entendre, it cannot be excluded that the author of the Fourth Gospel wanted to confer two meanings to $\gamma \rho \alpha \varphi \eta$ in 17:12. It would then refer to the fulfillment of both the Hebrew Scriptures and Jesus' prophetic utterances ${ }^{121}$.

\section{Bibliography}

Abbott E.A., Johannine Grammar (London: Adam \& Charles Black 1906).

Achelis H. (ed.), Hippolytus Werke, I/2: Hippolyt's kleinere exegetische und homiletische Schriften (Die griechischen Christlichen Schriftsteller der ersten drei Jahrhunderte; Leipzig: J.C. Hinrichs 1897).

120 Michaels, The Gospel of John, 870. Interestingly enough, in his earlier commentary on the Fourth Gospel, J.R. Michaels pointed as probable Ps 41:9 cited in Jn 13:18. See J.R. Michaels, John (Understanding the Bible; Grand Rapids, MI: Eerdmans 1989) 302.

121 I concur with E.D. Freed (Old Testament Quotations, 57) and C.S. Keener (John, 1059). Both are quoted in note no. 3 of the present article. 
Albl M.C., "And Scripture Cannot Be Broken". The Form and Function of the Early Christian Testimonia Collections (Supplements to Novum Testamentum 96; Leiden: Brill 1999).

Ashton J., Understanding the Fourth Gospel (Oxford: Oxford University Press 1993).

Ashton J., Understanding the Fourth Gospel. Second Edition (Oxford: Oxford University Press 2007).

Aune D.E., Revelation 6-16 (Word Biblical Commentary 52B; Nashville, TN: Thomas Nelson 1998).

Aune D.E., "Dualism in the Fourth Gospel and the Dead Sea Scrolls: A Reassessment of the Problem", Neotestamentica et Philonica. Studies in Honor of Peder Borgen (ed. D.E. Aune - T. Seland - J.H. Ulrichsen) (Supplements to Novum Testamentum 106; Leiden: Brill 2003) 281-303.

Barrett C.K., The Gospel according to St John. An Introduction with Commentary and Notes on the Greek Text (London: SPCK 1978).

Bauckham R., "The Qumran Community and the Gospel of John", The Dead Sea Scrolls Fifty Years after Their Discovery. Proceedings of the Jerusalem Congress, July 20-25, 1997 (ed. M. Galen - L.H. Schiffman - E. Tov - J.C. Vanderkam) (Jerusalem: Israel Exploration Society 2000) 105-115.

Baumgarten J.M., "The 'Sons of Dawn' in CDC 13,14-15 and the Ban on Commerce among the Essenes”, Israel Exploration Journal 33 (1983) 81-85.

Beasley-Murray G.R., John. Second Edition (Word Biblical Commentary 36; Dallas, TX: Word Books 1999).

Becker J., „Aufbau, Schichtung und theologiegeschichtliche Stellung des Gebetes in Johannes 17", Zeitschrift für die neutestamentliche Wissenschaft 60 (1969) 56-83.

Bennema C., Encountering Jesus. Character Studies in the Gospel of John. Second Edition (Minneapolis, MN: Fortress 2014).

Bennema C., "Judas (the Betrayer): The Black Sheep of the Family", Character Studies in the Fourth Gospel. Narrative Approach to Seventy Figures in John (ed. S.A. Hunt - D.F. Tolmie - R. Zimmermann) (Grand Rapids, MI: Eerdmans 2016) 360-372.

Bernard J.H., Gospel according to St. John (International Critical Commentary; Edinburgh: T \& T Clark 1928).

Billings J.S., "Judas Iscariot in the Fourth Gospel”, The Expository Times 51 (1939-40) 156-157.

Birdsall J.N., "John X.29", Journal for Theological Studies 11 (1960) 342-344.

Bjerg S., "Judas als Stellvertreter des Satans", Evangelische Theologie 52 (1992) 42-55.

Boismard M.-É. - Lamouille A., L'Évangile de Jean (Synopse des quatre Évangiles en français 3; Paris: Cerf 1987).

Borchert G.L., John 12-21 (The New American Commentary 25B; Nashville, TN: Broadman \& Holman Publishers 2002).

Borgen P., "The Use of Tradition in John 12:44-50", New Testament Studies 26 (1979-1980) 18-35.

Brown R.E., "The Qumran Scrolls and the Johannine Gospel and Epistles", Catholic Biblical Quarterly 17 (1955) 403-419.

Brown R.E., The Gospel According to John (XIII-XXI) (The Anchor Bible 29A; New York, NY: Doubleday 1970).

Brown R.E., An Introduction to the Gospel of John. Edited, Updated, Introduced, and Concluded by Francis J. Moloney (The Anchor Yale Bible Reference Library; New York, NY et al: Doubleday 2003).

Brownson J., "Neutralising the Intimate Enemy: The Portrayal of Judas in the Fourth Gospel", SBL 1992 Seminar Papers. One Hundred Twenty-Eighth Annual Meeting, November 21-24, 1992, The San Francisco Hilton, San Francisco, California (ed. E.H. Lovering) (SBL.SPS 31; Atlanta, GA: Scholars Press 1992) 49-60. 
Bultmann R., The Gospel of John. A Commentary (Philadelphia, PA: Westminster 1971).

Burney C.F., The Aramaic Origin of the Fourth Gospel (Oxford: Clarendon 1922).

Caba J., "Dalla parenesi lucana alla cristologia giovannea. Studio comparato di Lc 9,23-24 e Gv 12,25-26", Luca-Atti. Studi in onore di P. Emilio Rasco nel suo $70^{\circ}$ compleanno (ed. G. Marconi-G. O’Collins) (Assisi: Cittadella 1991) 72-104.

Carson D.A., The Gospel according to John (The Pillar New Testament Commentary; Grand Rapids, MI: Eerdmans - Leicester, U.K.: Apollos 1991).

Charles R.H. (ed.), The Greek Versions of the Testaments of the Twelve Patriarchs (Oxford: Clarendon 1908).

Charles R.H. (ed.), The Testaments of the Twelve Patriarchs (London: Clarendon 1908).

Charlesworth J.H. et al., Graphic Concordance to the Dead Sea Scrolls (Tübingen: Mohr Siebeck - Louisville: Westminster John Knox 1991).

Charlesworth J.H. et al. (ed.), The Dead Sea Scrolls. Hebrew, Aramaic, and Greek Texts with English Translations. II. Damascus Document, War Scroll, and Related Documents (Princeton Theological Seminary Dead Sea Scrolls Project 2; Tübingen: Mohr Siebeck - Louisville: Westminster John Knox Press 1995).

Charlesworth J.H., "A Critical Comparison of the Dualism in 1QS 3:13-4:26 and the "Dualism" Contained in the Gospel of John", John and the Dead Sea Scrolls (ed. J.H. Charlesworth) (New York, NY: Crossroad 1990) 76-106.

Charlesworth J.H., "Have the Dead Sea Scrolls Revolutionized Our Understanding of the New Testament?", The Dead Sea Scrolls Fifty Years after Their Discovery. Proceedings of the Jerusalem Congress, July 20-25, 1997 (ed. M. Galen et al.) (Jerusalem: Israel Exploration Society 2000) 116-132.

Coloe M.L. - Thatcher T. (ed.), John, Qumran, and the Dead Sea Scrolls. Sixty Years of Discovery and Debate (Early Judaism and Its Literature 32; Atlanta, GA: Society of Biblical Literature 2011).

Comfort P.W. - Barrett D.P. (ed.), The Text of the Earliest New Testament Greek Manuscripts. A Corrected, Enlarged Edition of the Complete Text of the Earliest New Testament Manuscripts (Wheaton: Tyndale House Publishers 2001).

Congemi Trolla B., "L'assenza della tribù di Dan nell'Apocalisse canonica (7,5-8) alla luce delle tradizioni sul patriarca Dan e sui suoi discendenti", Cristianesimi nell'antichità: fonti, istituzioni, ideologie a confronto (ed. A. D’Anna - C. Zamagni) (Spudasmata 117; Hildesheim et al.: G. Olms 2007) 39-58.

Cortès E., Los discursos de adiós de Gn 49 a Jn 13-17. Pistas para la historia de un género literario en la antigua literatura judía (Colectánea San Paciano 23; Barcelona: Herder 1976).

Daniélou J., "Le fils de perdition (Joh., 17, 12)", Mélanges d'histoire des religions offerts à Henri-Charles Puech (Paris: Presses universitaires de France 1974) 187-189.

Davies M., Rhetoric and Reference in the Fourth Gospel (Journal for the Study of the New Testament Supplement Series 69; Sheffield: JSOT Press 1992).

de Jonge M., Jewish Eschatology, Early Christian Christology and the Testaments of the Twelve Patriarchs. Collected Essays (Supplements to Novum Testamentum 56; Leiden: Brill 1991).

Denker F.W., "The viós Phrases in the New Testament", New Testament Studies 7 (1960-61) 94-95.

Destro A. - Pesce M., "Un confronto di sistemi. Il Vangelo di Giovanni e la Regola della communità di Qumran", Atti del VIII Simposio de Efeso su S. Giovanni Apostolo (ed. L. Padovese) (Turchia: la Chiesa e la sua storia 15; Roma: Istituto francescano di spiritualità - Pontificio Ateneo Antoniano 2001) 81-107.

Dodd C.H., The Interpretation of the Fourth Gospel (Cambridge: Cambridge University Press 1953). 
Evans C.A., "On the Quotation Formulas in the Fourth Gospel”, Biblische Zeitschrift 26 (1982) 79-83.

Fabris R., Giovanni. Traduzione e commento. Seconda edizione riveduta e ampliata (Commenti biblici; Roma: Borla 2003).

Freed E.D., Old Testament Quotations in the Gospel of John (Supplements to Novum Testamentum 11; Leiden: Brill 1965).

Gagné A., "Caractérisation des figures de Satan et de Judas dans le IVe Évangile: stratégie narrative et déploiement des intrigues de conflit", Science et esprit 55 (2003) 263-284.

García Martínez F., The Dead Sea Scrolls Translated. The Qumran Texts in English (Leiden: Brill - Grand Rapids, MI: Eerdmans ${ }^{2} 1996$ ).

Guilding A., The Fourth Gospel and Jewish Worship. A Study of the Relation of St. John's Gospel to the Ancient Jewish Lectionary System (London: Oxford University Press - Clarendon 1960).

Haenchen E., John 2. A Commentary on the Gospel of John. Chapters 7-21 (Hermeneia; Philadelphia, PA: Fortress 1984).

Hammer I., "Eine klare Stellung zu Joh. 14.13b", Bibel und Kirche 14/2 (1959) 33-40.

Hanson A.T., The Prophetic Gospel. A Study of John and the Old Testament (Edinburgh: T \& T Clark 1991).

Hastings J. - Selbie J.A., A Dictionary of Christ and the Gospels (Edinburgh: T \& T Clark 1906).

Hill C.E., "Antichrist from the Tribe of Dan", Journal of Theological Studies 46 (1995) 99-117.

Huby J., "Un double problème de critique textuelle et d'interprétation. Saint Jean XVII, 11-12", Recherches de science religieuse 27 (1937) 408-421.

James M.R., The Apocryphal New Testament. A Collection of Apocryphal Christian Literature in an English Translation (Oxford: Clarendon 1924).

Keener C.S., The Gospel of John. A Commentary (Peabody, MA: Hendrickson 2003).

Klassen W., Judas. Betrayer or Friend of Jesus? (Minneapolis, MN: Fortress 1996).

Knapp G.Ch., H KAINH $\triangle \mathrm{IA \Theta HKH.} \mathrm{Novum} \mathrm{Testamentum} \mathrm{Graece.} \mathrm{Revognavit} \mathrm{atque} \mathrm{insignioris}$ lectionum varietatis et argumentorum notations subiunxit (Halle: Orphanotropheum 1787, $\left.{ }^{5} 1840\right)$.

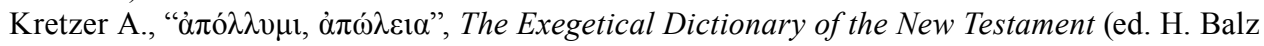
- G. Schneider) (Edinburgh: T \& T Clark 1990) I, 135-136.

Labahn M., "Jesus und die Autorität der Schrift im Johannesevangelium. Überlegungen zu einem spannungsreichen Verhältnis", Israel und seine Heilstraditionen im Johannesevangelium. Festgabe für Johannes Beutler SJ zum 70. Geburtstag (ed. M. Labahn - K. Scholtissek A. Strotmann) (Paderborn: Schöningh 2004) 185-206.

Lévi I., L'Ecclésiastique ou la Sagesse de Jésus, fils de Sira. Texte original hébreu (Bibliothèque de l'école des hautes études. Sciences religieuses 10; Paris: Leroux 1898).

Lévi I., The Hebrew Text of the Book of Ecclesiasticus (Semitic Study Series 3; Leiden: Brill 1969).

Lightfoot R.H., St. John's Gospel. A Commentary (Oxford: Oxford University Press 1956).

Lindars B., The Gospel of John (New Century Bible Commentary; London: Marshall, Morgan \& Scott 1972).

Lindars B., "Traditions behind the Fourth Gospel”, L'Évangile de Jean. Sources, rédaction, théologie (Bibliotheca Ephemeridum Theologicarum Lovaniensium 44; Gembloux: Duculot Leuven: Leuven University Press 1987) 107-124.

Lorein G.W., The Antichrist Theme in the Intertestamental Period (Library of Second Temple Studies - Journal for the Study of the Pseudepigrapha Supplement Series 44; London: Sheffield Academic Press 2003).

Martín Nieto E., “El nombre de Dios en S. Jh., 17, 11-12”, Estudios Biblicos 11 (1952) 5-30. 
Menken M.J.J., Old Testament Quotations in the Fourth Gospel. Studies in Textual Form (Contributions to Biblical Exegesis and Theology 15; Kampen: Pharos 1996).

Merx A., Das Evangelium des Johannes nach der Syrischen im Sinaikloster gefundenen Palimsesthandschrift (Berlin: Reimer 1911).

Michaels J.R., John (Understanding the Bible; Grand Rapids, MI: Eerdmans 1989).

Michaels J.R., "Betrayal and the Betrayer: The Uses of Scripture in John 13.18-19", The Gospels and the Scriptures of Israel (ed. C.A. Evans - W.R. Stegner) (Journal for the Study of the New Testament. Supplement Series 104 - Studies in Scripture in Early Judaism and Christianity 3; Sheffield: Sheffield Academic Press 1994) 459-474.

Michaels J.R., The Gospel of John (The New International Commentary on the New Testament; Grand Rapids, MI: Eerdmans 2010).

Moloney F.J., Glory not Dishonor: Reading John 13-21 (Minneapolis, MN: Fortress 1998).

Moloney F.J., The Gospel of John (Sacra Pagina 4; Collegeville, MN: The Liturgical Press 1998).

Moloney F.J., "The Gospel of John as Scripture”, Catholic Biblical Quarterly 67 (2005) 454-468.

Moloney F.J., The Gospel of John. Text and Context (Biblical Interpretation Series 72; Boston Leiden: Brill 2005).

Moloney F.J., "What Came First - Scripture or Canon? The Gospel of John as a Test Case", Salesianum 68 (2006) 7-20.

Moloney F.J., "The Gospel of John: The "End” of Scripture”, Interpretation 64 (2009) 356-366.

Moloney F.J., "«For as yet they did not know the Scripture» (John 20,9). A Study in Narrative Time", Irish Theological Quarterly 79/2 (2014) 97-111.

Moloney F.J., Johannine Studies 1975-2017 (Wissenschaftliche Untersuchungen zum Neuen Testament 372; Tübingen: Mohr Siebeck 2017).

Moody Smith D., "When Did the Gospels Become Scripture?", Journal of Biblical Literature 119 (2000) 3-20.

Morgen M., “«Perdre sa vie». Jn 12,25: un dit traditionnel?”, Revue des sciences religieuses 69/1 (1995) 29-46.

Morris L., The Gospel according to John. Revised Edition (Grand Rapids, MI: Eerdmans 1995).

Murphy R.E., "Šahat in the Qumran Literature”, Biblica 39 (1958) 61-66.

Murray L., "The Church Fathers and the Fall of Judas. Grace, Predestination and Free Will among Early Modern Catholic Biblical Commentaries", Augustiniana 65/3-4 (2015) 185-203.

Neirynck F., "Saving/Losing One's Life. Luke 17,33 (Q?) and Mark 8,35", Evangelica III. 19922000. Collected Essays (Bibliotheca Ephemeridum Theologicarum Lovaniensium 150; Leuven: Leuven University Press 2001) 480-503.

North W.E.S., "«The Scripture» in John 17.12”, A Journey Round John. Tradition, Interpretation and Context in the Fourth Gospel (Library of the New Testament Studies 534; London et al.: Bloomsbury 2015) 45-56.

North W.E.S., "Judas Iscariot and Satan in the Fourth Gospel", A Journey Round John. Tradition, Interpretation and Context in the Fourth Gospel (Library of the New Testament Studies 534; London et al.: Bloomsbury 2015) 21-24.

Obermann A., Die christologische Erfüllung der Schrift im Johannesevangelium: Eine Untersuchung zur johanneischen Hermeneutik anhand der Schriftzitate (Wissenschaftliche Untersuchungen zum Neuen Testament 2/83; Tübingen: Mohr Siebeck 1996).

Pokorny P., "Lukas 17,33parr. - Die Geschichte Jesu und ein (damals) bekanntes Sprichwort", For the Children, Perfect Instruction. Studies in Honor of Hans-Martin Schenke on the Occasion of the Berliner Arbeitskreis für koptisch-gnostische Schriften's Thirtieth Year (ed. H.-G. Bethge - S. Emmel - K.L. King) (Nag Hammadi and Manichaean Studies 54; Leiden: Brill 2002) 387-398. 


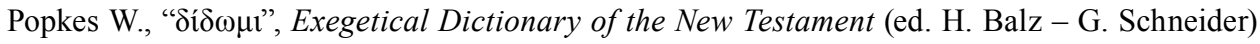
(Edinburgh: T \& T Clark 1990) I, 320-322.

Quast K., Reading the Gospel of John. An Introduction (New York, NY: Paulist 1991).

Rabin C., The Zadokite Documents (London: Clarendon 1954).

Rebell W., "«Sein Leben verlieren» (Mark 8,35 parr.) als Strukturmoment vor- und nachösterlichen Glaubens", New Testament Studies 35 (1989) 202-218.

Reim R., Studien zum alttestamentlichen Hintergrund des Johannesevangeliums (Society for New Testament Studies Monograph Series 22; Cambridge: Cambridge University Press 1974).

Sanders J.N. - Mastin B.A., A Commentary on the Gospel according to St John (London: Adam \& Charles Black 1968).

Schnackenburg R., The Gospel According to St John, Volume Three. Commentary on Chapters 12-21 (Herder's Theological Commentary on the New Testament; New York, NY: Crossroad 1990).

Schuchard B., Scripture within Scripture. The Interrelationship of Form and Function in the Explicit Old Testament Citations in the Gospel of John (Society of Biblical Literature Dissertation Series 133; Atlanta, GA: Scholars Press 1992).

Smend R., Die Weisheit des Jesus Sirach (Berlin: Reimer 1906).

Smith C.R., "The Portrayal of the Church as the New Israel in the Names and Order of the Tribes in Revelation 7.5-8", Journal for the Study of the New Testament 39 (1990) 111-118.

Sproston W.E., "Satan in the Fourth Gospel", Studia Biblica 1978. II. Papers on the Gospels. Sixth International Congress on Biblical Studies, Oxford 3-7 April 1978 (ed. E.A. Livingstone) (Journal for the Study of the New Testament Supplement Series 2; Sheffield: Sheffield Academic Press 1980) 307-311.

Sproston W.E., "«The Scripture» in John 17:12”, Scripture: Meaning and Method. Essays Presented to Anthony Tyrrell Hanson for His Seventieth Birthday (ed. B.P. Thompson) (Hull: University of Hull 1987) 24-36.

Tenney M.C., "John", The Expositor's Bible Commentary. IX. John and Acts (Grand Rapids, MI: Eerdmans 1981) 1-203.

Thompson M.M., John. A Commentary (The New Testament Library; Louisville: Westminster John Knox 2015).

Van Belle G., „L'accomplissement de la parole de Jésus. La parenthèse de Jn 18,9”, The Scriptures in the Gospels (ed. C.M. Tuckett) (Bibliotheca Ephemeridum Theologicarum Lovaniensium 131; Leuven: Leuven University Press 1997) 617-627.

Vanderkam J.C., The Book of Jubilees (Corpus Scriptorum Christianorum Orientalium 511 / Scriptores Aethiopici 88; Lovanii: Peeters 1989).

von Wahlde U.C., "Judas, the Son of Perdition, and the Fulfillment of Scripture in John 17:12", The New Testament and Early Christian Literature in Greco-Roman Context. Studies in Honor of David E. Aune (ed. J. Fotopoulos) (Supplement to Novum Testamentum 122; Leiden: Brill 2006) $167-181$.

von Wahlde U.C., The Gospel and Letters of John. II. Commentary on the Gospel of John (Eerdmans Critical Commentary; Grand Rapids, MI: Eerdmans 2010).

von Wahlde U.C., The Gospel and Letters of John. III. Commentary on the Three Johannine Letters (Eerdmans Critical Commentary; Grand Rapids, MI: Eerdmans 2010).

Westcott B.F., The Gospel according to St John. The Authorized Version with Introduction and Notes (London: John Murray 1892).

Wilcox M., "The Composition of John 13:21-30", Neotestamentica et semitica. Studies in Honour of Matthew Black (ed. E.E. Earle - M. Wilcox - M. Black) (Edinburg: T \& T Clark 1969) 143-156.

Wright W.M., "Greco-Roman Character Typing and the Presentation of Judas in the Fourth Gospel”, Catholic Biblical Quarterly 71 (2009) 544-559. 
